\title{
Pré-história na foz do rio Chapecó
}

\author{
Antoine Lourdeau ${ }^{1}$, Mirian Carbonera ${ }^{2}$, Marcos César Pereira Santos ${ }^{3}$, Sirlei Hoeltz ${ }^{4}$, Michel Fontugne ${ }^{5}$, \\ Christine Hatté ${ }^{6}$, Sergio Francisco Serafim Monteiro da Silva ${ }^{7}$, Pierluigi Rosina ${ }^{8}$, \\ Lívia de Oliveira e Lucas ${ }^{9}$, Amélie Da Costa ${ }^{10}$, Cécile Foucher ${ }^{11}$, \\ Juliana Betarello Ramalho ${ }^{12}$,Francieli Kuczkovski ${ }^{13}$,Juliano Bitencourt Campos ${ }^{14}$, \\ Sibeli Aparecida Viana ${ }^{15}$, Ana Lucia Herberts ${ }^{16}$
}

Palavras-chave: Alto rio Uruguai; Sítio ACH-LP-07; Debitagem laminar; Cerâmica Guarani; Pré-história do Sul do Brasil.

Mots clés: Haute vallée du fleuve Uruguay; Site ACH-LP-07; Débitage laminaire; Céramique Guarani; Préhistoire du Sud du Brésil.
Resumo: O alto rio Uruguai é uma área importante para compreender o povoamento pré-histórico da bacia do rio da Prata. Nela foram localizados sítios de caçadorescoletores, referentes ao passado mais antigo da região, e de grupos ceramistas relacionados às unidades arqueológicas Tupiguarani e Taquara-Itararé. Este artigo apresenta os primeiros resultados das pesquisas realizadas no sítio ACH-LP-07 situado próximo à foz do rio Chapecó, à margem direita do rio Uruguai, no oeste de Santa Catarina. O rio apresentou várias ocupações de populações de caçadores-coletores no início do Holoceno, caracterizadas por uma variabilidade nas produções de pedra lascada, onde se destaca a produção de lâminas por uma debitagem específica. No último milênio, o local também foi povoado por grupos ceramistas Guarani. O sítio tem trazido diferentes contribuições a respeito dessas antigas sociedades, especialmente as modalidades de ocupação e de sucessão dos grupos humanos no alto rio Uruguai.

Résumé: La haute vallée du fleuve Uruguay est une zone importante pour comprendre le peuplement préhistorique du bassin du Rio de la Plata. On y a découvert les sites les plus anciens de la région, associés à des occupations de chasseurs-cueilleurs et des groupes céramistes des traditions Tupiguarani et Taquara-Itararé. Cet article a pour objectif de présenter les premiers résultats des recherches faites sur le site ACH-LP-07 situé proche de l’embouchure du fleuve Chapecó, sur la rive droite du fleuve Uruguay, dans louest de l'état de Santa Catarina. Celui-ci présente plusieurs occupations de chasseurs-cueilleurs du début de l'Holocène, caractérisées par une variabilité des productions lithiques, en particulier l'obtention de lames par un débitage spécifique. Dans le dernier millénaire l’endroit a également été peuplé par des groupes céramistes de la tradition Guarani. Le site a apporté différentes contributions sur ces sociétés anciennes, spécialement sur les modalités d’occupation et de succession des groupes humains dans la haute vallée du fleuve Uruguay.

Recebido em 19 de setembro de 2016. Aprovado em $1^{\circ}$ de outubro de 2016.

\footnotetext{
${ }^{1}$ Doutor em Pré-história pela Université Paris Ouest Nanterre La Défense (UPOND)/França. Professor do Muséum National d’Histoire Naturelle (MNHN)/França e do Programa de Pós-graduação de Arqueologia da Universidade Federal de Sergipe (UFS). E-mail: antoine.lourdeau@mnhn.fr. ${ }^{2}$ Doutora em Arqueologia pela Universidade de São Paulo (USP). Responsável pelo Centro de Memória do Oeste de Santa Catarina (CEOM) e professora do Programa de Pós-graduação em Ciências Ambientais (Unochapecó).

${ }^{3}$ Doutorando em Arqueologia da Universitá degli Studi di Ferrara (UNIFE)/Itália. Funcionário da Universidade do Extremo Sul Catarinense (UNESC).

${ }^{4}$ Doutora em História pela Pontíficia Universidade Católica do Rio Grande do Sul (PUCRS). Arqueóloga na Archeo Pesquisas Arqueológicas.

${ }^{5}$ Pesquisador do Laboratoire des Sciences du Climat et de l'Environnement, Institut Pierre Simon Laplace (LSCE/IPSL), Commissariat à l'Energie Atomique (CEA)-Centre National de la Recherche Scientifique (CNRS)-Université de Versailles Saint-Quentin (UVSQ), Université Paris Saclay/ França.

${ }^{6}$ Doutora em Geologia pela Université Paris XI. Pesquisadora do LSCE/IPSL, CEA-CNRS-UVSQ, Université Paris Saclay/ França.

${ }^{7}$ Doutor em Arqueologia pela USP. Professor da Universidade Federal de Pernambuco (UFPE).

${ }^{8}$ Doutor em Geologia pela UNIFE/Itália. Professor do Instituto Politécnico de Tomar (IPT)/Portugal.

${ }^{9}$ Doutoranda em Arqueologia na UFS. Funcionária da Universidade Federal do Vale do São Francisco (UNIVASF).

${ }^{10}$ Doutoranda em Pré-história na UPOND/França.

${ }^{11}$ Doutoranda em Arqueologia na Université Paris 1 Panthéon-Sorbonne/França.

${ }^{12}$ Doutoranda em História na Universidade Federal de Santa Catarina (UFSC).

${ }^{13}$ Graduada em História pela Universidade Federal da Fronteira Sul (UFFS). Funcionária do CEOM/Unochapecó.

${ }^{14}$ Doutor em Arqueologia pela Universidade de Trás-os-Montes e Alto Douro (UTAD). Professor da UNESC.

${ }^{15}$ Doutora em História pela PUCRS. Professora da Pontifícia Universidade Católica de Goiás (PUC-Goiás).

${ }^{16}$ Doutora em História pela PUCRS. Arqueóloga na Scientia Consultoria Científica.
} 


\section{Introdução}

Neste artigo, buscamos trazer novos dados sobre a pré-história na foz do rio Chapecó, no oeste de Santa Catarina. Os estudos têm sido desenvolvidos no âmbito de um programa de pesquisa francobrasileiro iniciado em 2013 por meio do projeto acadêmico "Povoamentos pré-históricos do alto rio Uruguai", que tem como objetivo principal entender as mais antigas ocupações humanas na região do alto Uruguai, no Oeste de Santa Catarina e no Noroeste do Rio Grande do Sul, através de pesquisas interdisciplinares de campo e laboratório.

Os dados apresentados neste trabalho referem-se às atividades de pesquisa nos setores $1 \mathrm{e}$ 2 do sítio ACH-LP-07 (Linha Policial 7), localizado à margem direita do rio Uruguai, no município de Águas de Chapecó, Santa Catarina. As informações descritas aqui provêm das etapas desenvolvidas entre 2013 e 2015, ainda em andamento em ambos os setores do sítio. E este apresenta ao menos dois grandes momentos: ocupações pré-ceramistas do início do Holoceno e uma ocupação com vestígios de grupos ceramistas da unidade arqueológica Guarani, do último milênio. As camadas mais antigas contêm vestígios líticos, os quais têm revelado uma variabilidade técnica significativa. Nesse contexto, a ocupação Guarani tem possibilitado a obtenção de novas informações, não somente a respeito da produção material, mas também sobre as formas de sepultamento.

Sendo assim, o contexto do sítio ACH-LP-07 revela-se particularmente interessante para entender diferentes aspectos dessas culturas, bem como abordar como as populações humanas ocuparam e se sucederam no espaço e no tempo no alto rio Uruguai.

\section{Histórico das pesquisas e descrição da área}

Para a pré-história do Sul do Brasil, o alto rio Uruguai é uma área importante, pois apresenta desde sítios pré-ceramistas da passagem PleistocenoHoloceno até sítios ceramistas do Holoceno Tardio. Há, no entanto, um lapso difícil de documentar que compreende o Holoceno Médio. Apesar de serem registrados vários achados pré-históricos na região desde pelo menos a década de 1950, os sítios com contextos estratigráficos claros e bem datados são poucos.

Desde meados do século XX, os vestígios arqueológicos do alto rio Uruguai passaram a ser objeto de estudo e de preservação. Schmitz (1957) foi um dos pesquisadores precursores ao descrever um sítio Guarani em Itapiranga/SC. Novas pesquisas, mas principalmente registros de sítios, ocorreram nas décadas seguintes com os estudos desenvolvidos por Becker e Schmitz (1970), Piazza (1969, 1971), Rohr (1966, 1968, 1973, 1984) e Schmitz (1978).

Já a partir da década de 1980, as pesquisas arqueológicas passaram a ser realizadas basicamente em decorrência de projetos de licenciamento ambiental; por isso, para uma análise mais detalhada é importante consultar: Carbonera (2008) e Caldarelli e Lavina (2011). Foram empreendidas principalmente por Caldarelli (2010); De Masi e Artusi (1985); De Masi (2012); Goulart (1985a, 1985b, 1985c); Goulart (1987a, 1987b, 1988a, 1988b); Lavina (2004); Museu de Ciência e Tecnologia (2001); Silva, Monticelli e Domiks (1998). No entanto, nos últimos anos, houve um esforço para a retomada de estudos acadêmicos, seja a partir de análises de coleções, ou de novas escavações, o que pode ser exemplificado pelos textos de Carbonera (2008, 2014); Carbonera e Schmitz (2011); Carbonera, Loponte e Silvestre (2015); Costa (2000); Oliveira (2009, 2011); Hoeltz e Brüggemann (2011, 2014); Hoeltz, Lourdeau e Viana (2015); Costa (2012); Loponte, Carbonera e Silvestre (2015); Lourdeau, Hoeltz e Viana (2014).

A região analisada neste artigo está localizada nas proximidades da foz do rio Chapecó com o rio Uruguai. Neste local, em fins do século XIX, foram encontrados vestígios arqueológicos descritos por Maximiliano Beschören. Como topógrafo, realizou expedições de levantamento a pedido do Governo do Rio Grande Sul, entre 1875 a 1887. Segundo ele, foram encontrados velhos utensílios e sepultamentos humanos antigos:

$\mathrm{Na}$ foz do rio Chapecó [hoje município de Águas de Chapecó], perto da recémdescoberta fonte medicinal, encontrouse, quando se procurava preciosidades jesuítas, sob oito palmos de terra, grandes pratos de argila de 1 a 2 metros de 
diâmetro, com restos de ossos humanos, na maioria, reduzidos a pó. Seriam esses restos de pessoas que procuravam a cura junto à fonte? (BESCHÖREN, 1989 [1889], p. 51-52).

$\mathrm{O}$ relato descreve vestígios relacionados à unidade arqueológica Guarani, inclusive vestígios de um tipo de sepultamento que, como veremos neste trabalho, ainda se encontra na área.

João Alfredo Rohr, na década de 1960, levantou 52 sítios arqueológicos na região de Itapiranga, dois sítios em Mondaí, quatro em São Carlos, um sítio Guarani em Águas de Chapecó, dois sítios Guarani em Caxambu do Sul, além de um sítio de sinalização rupestre que, segundo o autor, constava de inscrições em bloco de diabásio que foi dinamitado pelos moradores (ROHR, 1984). Já à margem esquerda do rio Uruguai, o município de Alpestre/RS foi percorrido inicialmente por Danilo Lazarotto, entre os anos de 1972 e 1973. O mesmo encontrou 24 sítios superficiais, a grande maioria Guarani, assim como dois Taquara-Itararé (SILVA; MONTICELLI; DOMIKS, 1998).

Antes da construção da Usina Hidrelétrica de Foz do Chapecó, nenhum sítio havia sido escavado em Águas de Chapecó. Os primeiros levantamentos na área da usina foram realizados por Silva, Monticelli e Domiks (1998), pesquisadores que, a partir de prospecções assistemáticas, localizaram 38 sítios e ocorrências, principalmente associados à tradição Guarani. Outra etapa foi realizada por Lavina (2004), quando, por meio de prospecções sistemáticas, registrou 12 sítios e 21 ocorrências. Do total de sítios, nove encontravam-se à margem direita do rio Uruguai (ACH-SU-01 a 03 e ACH-LP-01 a 06) e três à margem esquerda (ALP-AA-01 a 03). Exceto os sítios ALP-AA-01 e 02, nos quais foi encontrado material lítico (lascas e blocos lascados de arenito silicificado), os demais sítios foram associados ao período ceramista, principalmente à tradição Guarani (Figura 1).

Posteriormente, as atividades tiveram prosseguimento com a equipe da Scientia Consultoria Científica, durante 2006 e 2007, quando os sítios foram reavaliados e escavados. As escavações, bem como as análises laboratoriais, permitiram evidenciar que três sítios eram mais antigos: o sítio Alto Alegre 3 (ALP-AA-03), em Alpestre/RS, e os sítios Linha
Policial 1 e 3 (ACH-LP-01 e ACH-LP-03), em Águas de Chapecó/SC (CALDARELLI, 2010; HOELTZ; BRÜGGEMANN, 2011, 2014) (Figura 1).

Esses três sítios apresentam um contexto sedimentar e arqueológico muito similar, e estão localizados em uma área plana, relativamente extensa $\left(216 \mathrm{~m}^{2}\right.$ para ALP-AA-03, $2480 \mathrm{~m}^{2}$ para ACH-LP-01 e $2160 \mathrm{~m}^{2}$ para ACH-LP-03), em patamares à beira do rio Uruguai, ao lado de córregos, perto da foz do rio Chapecó (CALDARELLI, 2010). Foram escavados por quadrículas de $4 \mathrm{~m}^{2}$ repartidas em toda a área, totalizando mais de $10 \%$ da superfície total de cada sítio. As intervenções atingiram uma profundidade máxima de 70 a $170 \mathrm{~cm}$, em função da quantidade de material arqueológico encontrado.

Os vestígios líticos lascados foram produzidos principalmente em arenito silicificado, sílex, metalamito, quartzo e basalto. São compostos de lascas, núcleos e instrumentos. Nesta categoria, destaca-se a presença de uma quantidade importante de lâminas: 19 no sítio ALP-AA-03; 51 no sítio ACH-LP-01 e 107 para o sítio ACH-LP-03. Foram também encontradas possíveis áreas de combustão, com concentrações de carvão que permitiram obter quatro datas radiocarbônicas (Tabela 1).

As lâminas dos sítios ALP-AA-03, ACHLP-01 e ACH-LP-03 foram alvo de estudos detalhados realizados por Lourdeau, Hoeltz e Viana (2014) e Hoeltz, Lourdeau e Viana (2015). As análises mostraram que a produção seguiu um método único, com uma produção unidirecional e um preparo centrípeto do núcleo, que as técnicas usadas para o lascamento das lâminas foram a percussão com percutor de pedra e a percussão com percutor orgânico, e que esses suportes eram destinados a várias funções.

$\mathrm{Na}$ área, também foi possível realizar seis datações que correspondem às ocupações recentes por sociedades ceramistas associadas à unidade arqueológica Guarani (Tabela 1). Estas ocupações estavam localizadas nos patamares planos, caracterizadas pela presença de solo escuro além de abundante cerâmica (CALDARELLI, 2010). Ainda segundo os autores, foram encontrados objetos líticos, estruturas de combustão, fauna e estruturas funerárias. 
Tabela 1 - Cronologia dos sítios da área do canteiro da UHE Foz do Chapecó (“years BP”: anos antes do presente, 1950 por convenção. "cal. years BP": anos calibrados antes do presente, 1950 por convenção. Os intervalos das datas calibradas são dados com 2 sigma, ou seja, um nível de confiança de 95,4\%).

\begin{tabular}{cccc}
\hline $\begin{array}{c}\text { Idade 14C } \\
(\text { years BP) }\end{array}$ & $\begin{array}{c}\text { Data calibrada }(\mathbf{2 \sigma}) \\
(\text { cal. years BP) }\end{array}$ & Sítio & Num. Laboratório \\
\hline $110 \pm 40$ & {$[150 ; 0]$} & ACH-SU-02-12 & Beta236427 \\
$320 \pm 40$ & {$[510 ; 280]$} & ACH-SU-03-M2-1 & Beta226115 \\
$360 \pm 40$ & {$[510 ; 310]$} & ACH-SU-01-C3-340 & Beta236426 \\
$400 \pm 40$ & {$[520 ; 420]$} & ACH-SU-01-C3-524 & Beta236324 \\
$470 \pm 40$ & {$[540 ; 490]$} & ACH-SU-03-M2-2 & Beta226116 \\
$750 \pm 50$ & {$[740 ; 650]$} & ALP-AA-06-51 & Beta236425 \\
$6.990 \pm 70$ & {$[7.960 ; 7680]$} & ACH-LP-03 & Beta236421 \\
$7.260 \pm 60$ & {$[8.180 ; 7960]$} & ACH-LP-03 & Beta236420 \\
$8.270 \pm 70$ & {$[9.460 ; 9.020]$} & ACH-LP-01 & Beta236423 \\
$8.370 \pm 60$ & {$[9.500 ; 9260]$} & ACH-LP-01 & Beta236422 \\
\hline
\end{tabular}

Fonte: Caldarelli (2010).

Segundo Caldarelli (2010), a cerâmica Guarani apresentou características dessa cultura, sendo confeccionada principalmente a partir da técnica do acordelamento, quase $50 \%$ dos fragmentos apresentaram queima oxidante incompleta, o acabamento corrugado foi observado em mais de
$50 \%$ do material analisado; e a predominância dos diâmetros de boca entre 8 e $30 \mathrm{~cm}$. Por fim, cabe destacar a presença de fragmentos de cerâmica Taquara-Itararé junto a uma das seis estruturas funerárias encontradas (CALDARELLI, 2010).

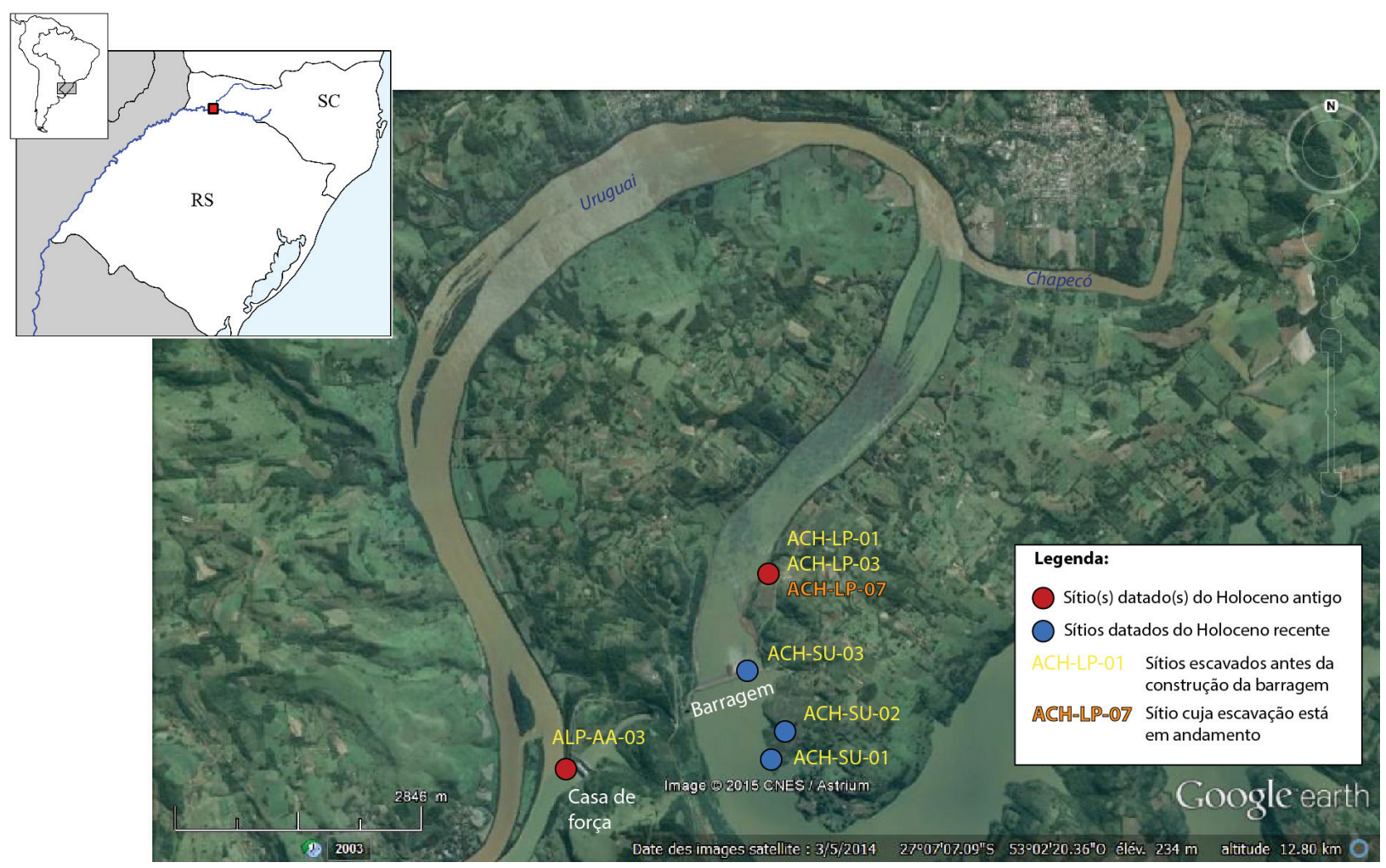

Figura 1 - Foto de satélite que indica a localização dos principais sítios arqueológicos da foz do Chapecó, no alto Uruguai, em Santa Catarina e Rio Grande do Sul

Fonte: Elaborada pelos autores (2016) (Foto satélite: Google Earth). 
Dias e Hoeltz (2010) mencionam que o material lítico dos sítios associados à unidade arqueológica Tupiguarani que foi encontrado na área compõe-se principalmente de lascas retocadas obtidas por debitagem bipolar de rochas criptocristalinas e à produção de peças bifaciais de portes avantajados de arenito silicificado e basalto, medindo entre 8 e $20 \mathrm{~cm}$. Ainda segundo as autoras, os artefatos seriam talhadores bifaciais bumerangoides, afiadores de arenito, percutores, perfuradores, lâminas de machado polidas e tembetás (DIAS; HOELTZ, 2010).

\section{O sítio ACH-LP-07}

O sítio ACH-LP-07 localiza-se em uma plataforma à margem direita do rio Uruguai, a uma altitude entre 225 e $237 \mathrm{~m}$, a aproximadamente 1 km à jusante da UHE Foz do Chapecó (Figura 1). Estende-se por uma área de $400 \mathrm{~m}$ de comprimento e, no máximo, $50 \mathrm{~m}$ de largura. A área foi cavada quase inteiramente e em profundidade na época da construção da barragem. Foi preenchida, logo após a finalização da escavação, com sedimentos não originais e nivelada a uma altitude constante de $237,5 \mathrm{~m}$ para permitir a construção de tanques para criação de peixes. No entanto, a margem do rio foi poupada destes trabalhos de terraplanagem preservando seus sedimentos originais e, portanto, os vestígios arqueológicos lá encontrados.

Os sítios vizinhos descobertos por pesquisas preventivas, ACH-LP-01 e ACH-LP-03 parecem ter sido completamente destruídos pelas atividades relacionadas com a construção da hidrelétrica. Sendo assim, fica impossível a associação direta entre esses locais e ACH-LP-07. As escavações realizadas, em 2014 e 2015, concentraram-se em dois setores (Figura 2).

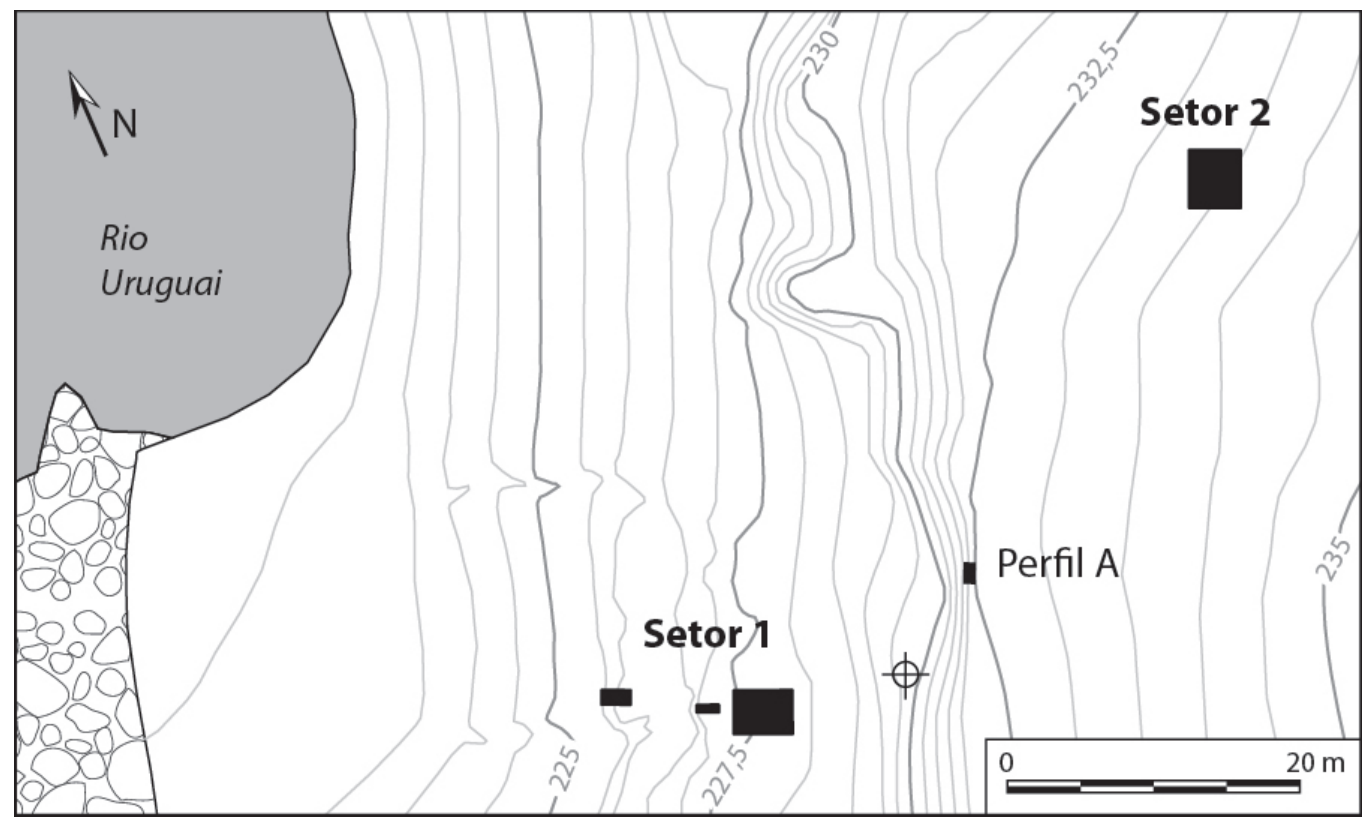

Figura 2 - Topografia e posição dos setores de escavação do sítio ACH-LP-07 Fonte: Elaborada pelos autores (2016).

$\mathrm{O}$ setor 1 encontra-se à margem do rio, em uma zona onde a erosão do pacote sedimentar delimitou vários patamares, revelando diferentes níveis de material arqueológico em contexto. O setor 2 encontra-se a $50 \mathrm{~m}$ do setor 1 , na parte superior da plataforma. Sua posição foi determinada pelo encontro casual de um conjunto composto de um recipiente cerâmico com tampa, cuja borda da primeira e a parte final da segunda afloravam na superfície. O descobrimento de restos ósseos em seu interior permite interpretá-lo como urna funerária. O setor 2 vem sendo escavado para obter uma visão completa da sequência estratigráfica da área, inclusive os níveis superiores que são ausentes no setor 1. Foi também realizada uma limpeza de um corte natural entre os dois setores (perfil A). 
As observações de campo, juntamente com os resultados das análises granulométricas, permitem distinguir três unidades sedimentares sucessivas ao longo da sequência de ACH-LP-07 (Figura 3). De cima para baixo, a camada I compreende a superfície atual da plataforma, antes da erosão resultante da construção da barragem. Há um sedimento argilo- arenoso composto por aproximadamente $50 \%$ de areia, 30\% de argila e $20 \%$ de silte. Sua cor é marromavermelhada nos primeiros centímetros, e depois tende a marrom-claro. Esses sedimentos foram encontrados em todo o setor 2 e na parte superior do perfil A. É na camada I que está posicionado o nível arqueológico 1 do setor 2 e a urna cerâmica.

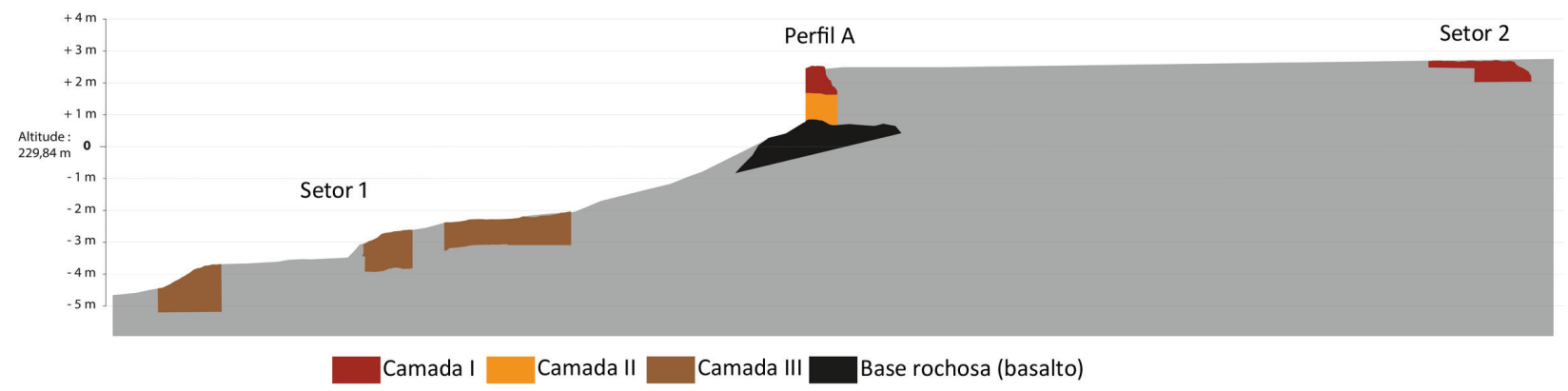

Figura 3 - Sequência sedimentar geral do sítio ACH-LP-07

Fonte: Elaborada pelos autores (2016).

A camada II é atualmente conhecida apenas no perfil A, entre 1 e $2 \mathrm{~m}$ de profundidade. É composta de um sedimento argiloso marrom com aproximadamente $40 \%$ de argila, $40 \%$ de areia e $20 \%$ de silte. Até o momento, não há conhecimento de nenhum vestígio arqueológico nesta camada.

A camada III corresponde a todo o sedimento do setor 1. É argila quase pura, composta por cerca de $50 \%$ de argila, de $40 \%$ de silte, e entre $10 \%$ de areia. Há uma variação na coloração dos sedimentos, entre o amarelo e o marrom-escuro. Os carvões encontrados durante a escavação permitiram datar esse sedimento entre 9.500 e 11.300 cal AP. A parte superior da camada III é rica em vestígios arqueológicos.

As diferenças de cor e textura entre essas camadas não estão bem marcadas. Passa-se de forma progressiva de um sedimento ao outro, de forma que durante a escavação é difícil perceber essas transições. Ademais, cada camada corresponde a um pacote sedimentar relativamente espesso (1 m para as camadas I e II e pelo menos $3 \mathrm{~m}$ para a camada
III). Assim, cada camada pode ter sido depositada ao longo de um período de tempo relativamente longo, e conter vários níveis arqueológicos.

\section{Níveis arqueológicos do setor 1}

As atividades do setor 1 foram realizadas em uma área de escavação principal e duas sondagens abaixo, em direção ao rio (Figura 4). A primeira tem uma superfície de $12 \mathrm{~m}^{2}$ e atingiu, até agora, uma profundidade de $1 \mathrm{~m}$. A sondagem E33/34 tem uma superfície $0,75 \mathrm{~m}^{2}$ e uma profundidade máxima de $1,20 \mathrm{~m}$. A sondagem G27/28 tem uma superfície de $2 \mathrm{~m}^{2}$ e uma profundidade máxima de $1,50 \mathrm{~m}$. A escavação desta última foi interrompida pelo afloramento de água no fundo, a uma profundidade de aproximadamente $2 \mathrm{~m}$ acima do nível médio do rio Uruguai. Nesse setor, dois conjuntos arqueológicos distintos foram encontrados. 


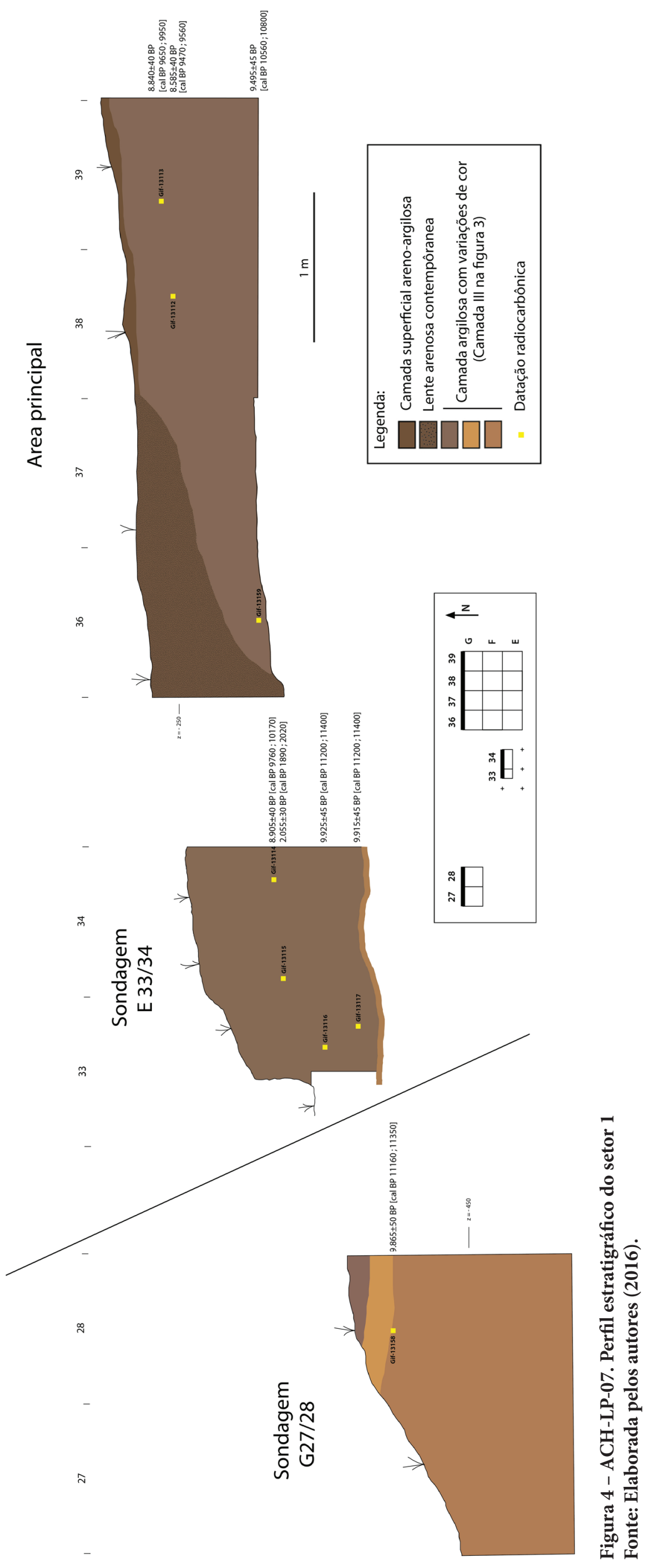




\section{Conjunto arqueológico inferior}

Encontra-se na parte superior da sondagem G27/28 e na parte profunda da sondagem E33/34, acima e abaixo de uma camada argilosa alaranjada de $20 \mathrm{~cm}$ de espessura. A composição granulométrica desta camada é a mesma do resto do sedimento do setor 1. Não se sabe ainda a origem desta camada alaranjada, mas as datações radiocarbônicas de carvões e as características técnicas do material lítico tendem a mostrar que os vestígios logo acima e logo abaixo da camada correspondem ao mesmo conjunto arqueológico, datado entre 11.400 e 11.150 cal. BP (Tabela 2).

Tabela 2 - ACH-LP-07-Setor 1 - Datas radiocarbônicas por AMS do conjunto inferior (“years BP”: anos antes do presente, 1950 por convenção. “cal. years BP”: anos calibrados antes do presente, 1950 por convenção. As idades foram calibradas com o programa OxCal (BRONK RAMSEY; LEE, 2013) utilizando a curva de calibração IntCal13 (REIMER et al., 2013). Os intervalos das datas calibradas são dados com 2 sigma, ou seja um nível de confiança de 95,4\%). Todas as datações foram feitas sobre carvão

\begin{tabular}{cccc}
\hline $\begin{array}{c}\text { Idade 14C } \\
(\text { years BP) }\end{array}$ & $\begin{array}{c}\text { Data calibrada }(\mathbf{2} \sigma) \\
(\text { cal. years BP) }\end{array}$ & Num. Laboratório & Observação \\
\hline $9.925 \pm 45$ & {$[11.400 ; 11.200]$} & Gif13116/SacA40193 & Acima da camada alaranjada \\
$9.91 \pm 45$ & {$[11.400 ; 11.200]$} & Gif13117/SacA40194 & Acima da camada alaranjada \\
$9.865 \pm 50$ & {$[11.350 ; 11.160]$} & Gif13158/SacA44480 & Abaixo da camada alaranjada \\
\hline
\end{tabular}

Fonte: Projeto Poparu (2016).

A superfície escavada do conjunto inferior encontra-se ainda bastante reduzida (menos de 2 $\mathrm{m}^{2}$ no total). Assim, a quantidade de vestígios nele encontrada é pouca. Na sondagem E33/34, cinco peças líticas foram achadas, e três na sondagem G27/28, ou seja, um total de oito objetos líticos, além de uma quantidade importante de carvões dispersos, sem estrutura aparente. O número limitado de peças ainda não permite uma boa caracterização técnica do material associado a esse nível.

Esses objetos correspondem a um instrumento maciço produzido sobre uma grande lasca cortical, uma grande lasca não cortical (essas duas fragmentadas por provável contato com o fogo), cinco lascas pequenas, algumas talvez de retoque unifacial, e um seixo apresentando marcas profundas de impactos repetidos em cada extremidade interpretado como percutor (Figura 5). Todos esses objetos são de sílex. As partes corticais, quando preservadas, demonstram que a matéria-prima foi coletada no rio, na forma de seixos rolados. Próximo ao sítio, até hoje, no leito do rio, existem praias de seixos com matéria-prima comparável. 


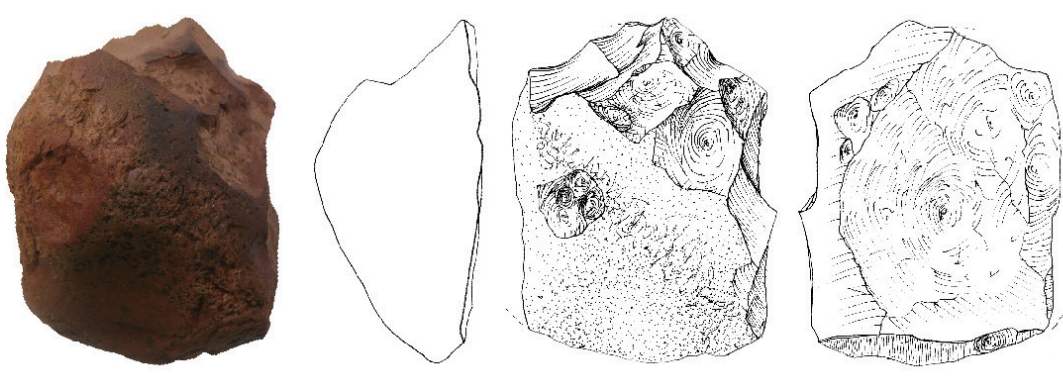

a.

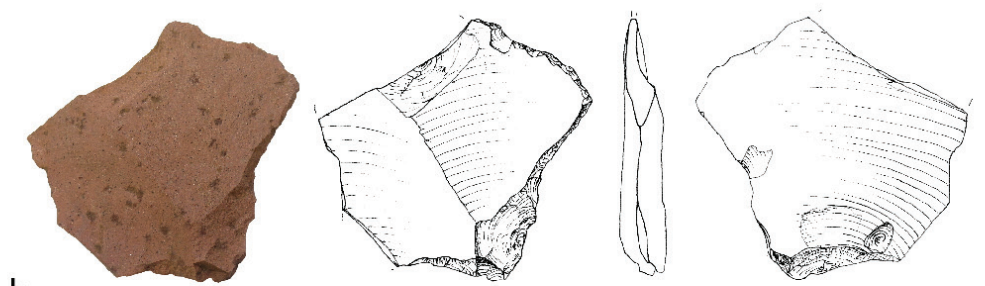

b.

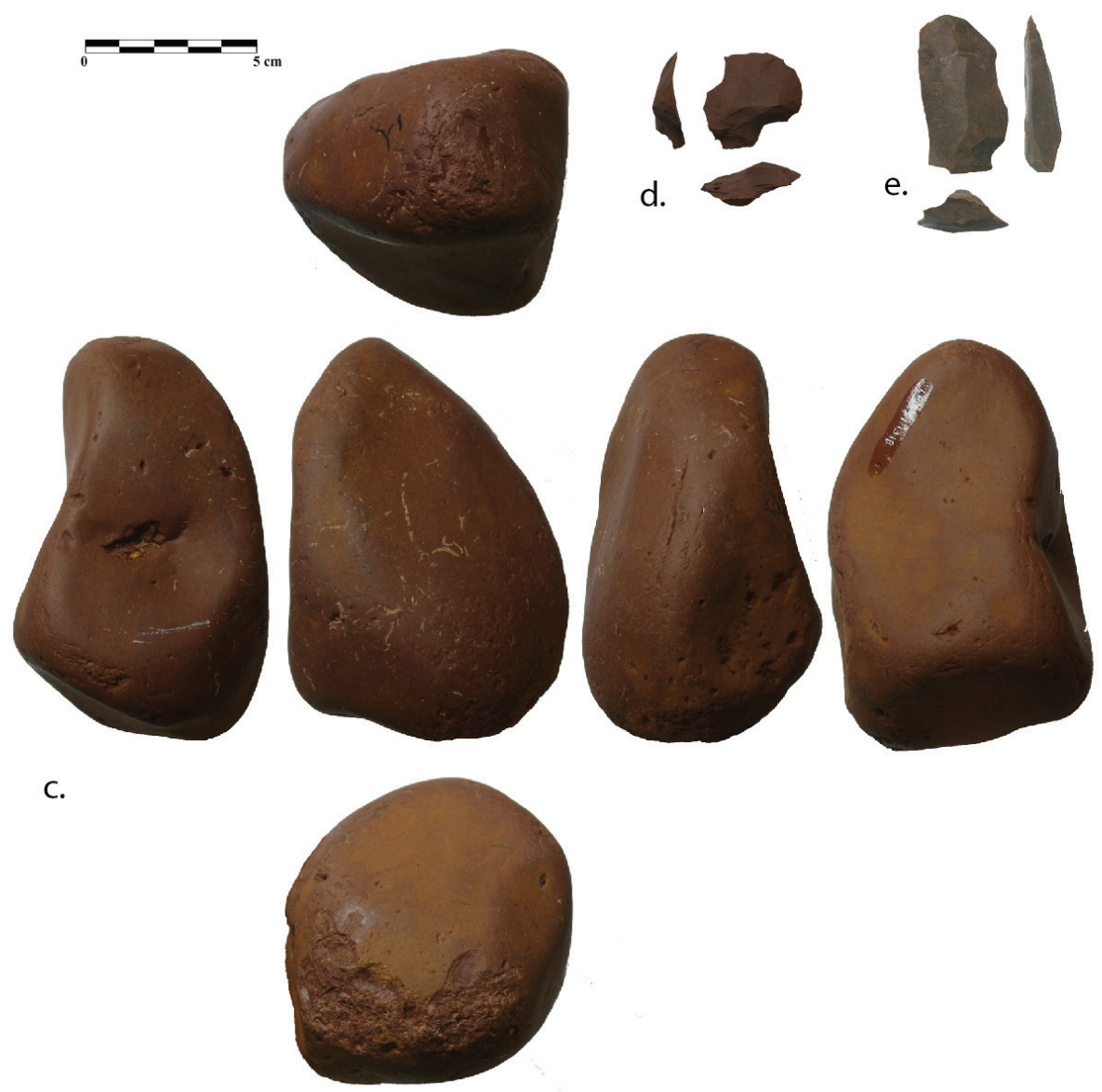

Figura 5 - ACH-LP-07 - Setor 1 - Artefatos líticos do conjunto arqueológico inferior Fonte: Elaborada pelos autores (2016).

\section{Conjunto arqueológico principal}

Esse conjunto corresponde à totalidade dos vestígios encontrados na área de escavação principal e no nível superior da sondagem E33/34.
Exceto por uma lente de areia (arqueologicamente estéril) correspondente a uma perturbação recente ao redor da quadra G36, os sedimentos nos quais se encontram os vestígios do conjunto arqueológico principal pertencem à mesma unidade estratigráfica 
de argila marrom-escura. É difícil distinguir, durante a escavação, as diferenças sedimentares dentro desse pacote argiloso. No entanto, a distribuição espacial do material arqueológico, concentrações de matérias-primas idênticas e remontagens de peças lascadas permitem fazer subdivisões verticais. Essas subdivisões demonstram que este conjunto arqueológico foi sendo depositado em vários momentos, como decorrência das sucessivas ocupações do sítio. No entanto, as datas demonstram que essas ocupações ocorreram dentro de uma faixa de tempo bastante reduzida, e os artefatos líticos não apresentam variedade notável de um nível ao outro.

Cinco datações radiocarbônicas foram efetuadas com carvões (Tabela 3). Três delas demonstram que esses níveis arqueológicos datam principalmente entre 10.000 e $9.500 \mathrm{cal}$ AP. Outra, obtida na base, propiciou uma data de $10.700 \mathrm{cal} \mathrm{BP}$ $(9.450 \pm 45 \mathrm{AP})$ (Tabela 2). A última idade, de 2.055 $\pm 40 \mathrm{AP}$, é discordante com o resto da sequência e deve corresponder a uma intrusão de material mais recente no nível arqueológico.

Tabela 3 - ACH-LP-07- Setor 1 - Datas radiocarbônicas por AMS do conjunto principal (“years BP”: anos antes do presente, 1950 por convenção. “cal. years BP”: anos calibrados antes do presente, 1950 por convenção. As idades foram calibradas com o programa OxCal (BRONK RAMSEY; LEE, 2013) utilizando a curva de calibração IntCal13 (REIMER et al., 2013). Os intervalos das datas calibradas são dados com 2 sigma, ou seja um nível de confiança de 95,4\%. Todas as datações foram feitas sobre carvão

\begin{tabular}{ccc}
\hline $\begin{array}{c}\text { Idade 14C } \\
\text { (years BP) }\end{array}$ & $\begin{array}{c}\text { Data calibrada }(\mathbf{2 \sigma}) \\
\text { (cal. years BP) }\end{array}$ & Num. Laboratório \\
\hline $8.585 \pm 40$ & {$[9.560 ; 9.470]$} & Gif13112/SacA40189 \\
$8.840 \pm 40$ & {$[9.950 ; 9.650]$} & Gif13113/SacA40190 \\
$8.905 \pm 40$ & {$[10.170 ; 9.760]$} & Gif13114/SacA40191 \\
$9.450 \pm 45$ & {$[10.800 ; 10.560]$} & Gif13159/SacA44481 \\
$2.055 \pm 40$ & {$[2.020 ; 1.890]$} & Gif13115/SacA40192 \\
\hline
\end{tabular}

Fonte: Projeto Poparu (2016).

Do ponto de vista arqueológico, todos os vestígios encontrados pertencem a um conjunto coerente em termos sedimentar, cronológico e cultural. O mesmo está organizado em pequenos níveis sucessivos de ocupação sub-horizontais, com uma inclinação em direção ao rio. A homogeneidade do sedimento e o fato de que cada nível apresenta uma densidade relativamente baixa de material tornam difícil sua distinção durante a escavação. Os vestígios arqueológicos correspondem a objetos líticos e carvões espalhados. Até agora, nenhuma estrutura organizada foi encontrada nesse conjunto arqueológico

O material lítico compõe-se atualmente de 517 peças, incluindo 217 estilhas, 195 lascas não retocadas, 73 fragmentos, 13 lâminas não retocadas, dez instrumentos e nove núcleos. As matérias-primas são variadas, incluindo sílex, arenito silicificado, calcedônia, quartzo hialino e basalto. Essa indústria é caracterizada por uma grande diversidade de esquemas operatórios.
A produção de lâminas é um elemento marcante desta indústria, como já tinha sido notado nos sítios ACH-LP-01, ACH-LP-03 e ALP-AA-3 (LOURDEAU; HOELTZ; VIANA, 2014; HOELTZ; LOURDEAU; VIANA, 2015) (Figura 6). Estas peças foram deixadas brutas ou retocadas. Os módulos são de comprimento bastante variado. Os perfis e talões, entre outros, demonstram o uso de diferentes técnicas de lascamento para a debitagem destes suportes. A percussão direta com percutor orgânico é evidenciada, bem como a percussão direta com pedra, tanto por percussão interna quanto marginal.

O exame das modificações das lâminas durante a sua confecção demonstra que serviram de suporte de instrumentos bastante variados. Os retoques são mais frequentemente laterais que distais, mas existem alguns raspadores distais. Sua extensão é variável. Eles formam gumes com ângulos mais ou menos abertos, lineares ou denticulares, retilíneos ou convexos. Gumes não retocados parecem também ter sido objetos de um uso direto. Alguns retoques 
parecem mais ligados a um objetivo de preensão do que transformativo. Um teste traceológico demonstrou a preservação de marcas de uso, revelando um interessante potencial para um estudo futuro.

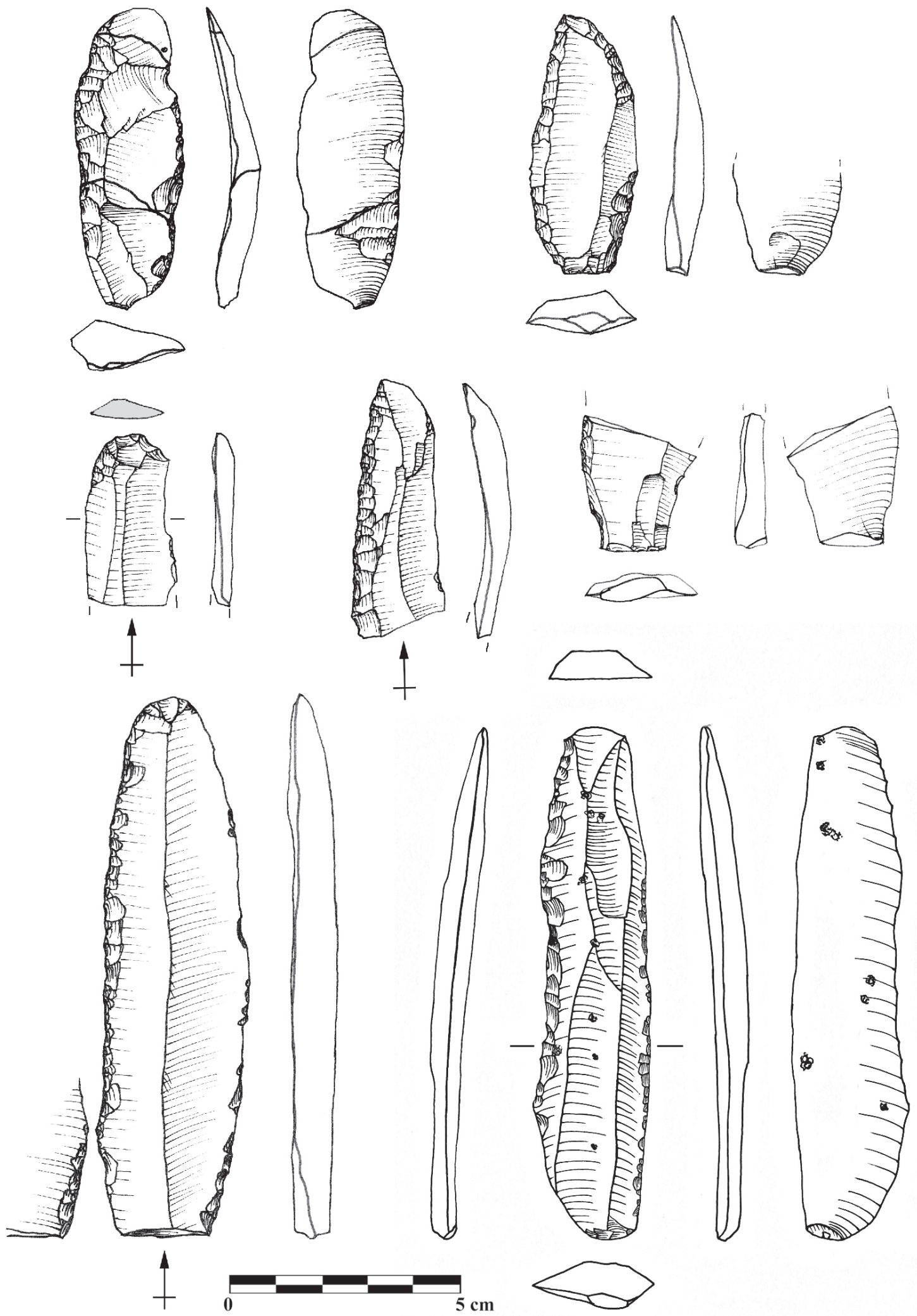

Figura 6 - ACH-LP-07, Setor 1. Lâminas do conjunto arqueológico principal Fonte: Elaborada pelos autores (2016). 
Nenhum núcleo laminar foi encontrado na área de escavação até o momento. As coleções de superfície do sítio ACH-LP-07; no entanto, forneceram alguns núcleos laminares plenamente coerentes com as lâminas encontradas no contexto em termos de métodos e técnicas (Figura 7). A estrutura do núcleo é padronizada. Caracteriza-se por um plano traseiro e um único plano de percussão, a produção das lâminas sendo unidirecional. A superfície de debitagem é convexa, mas relativamente "plana", sendo esta última preparada, quando necessário, de acordo com um método centrípeto.
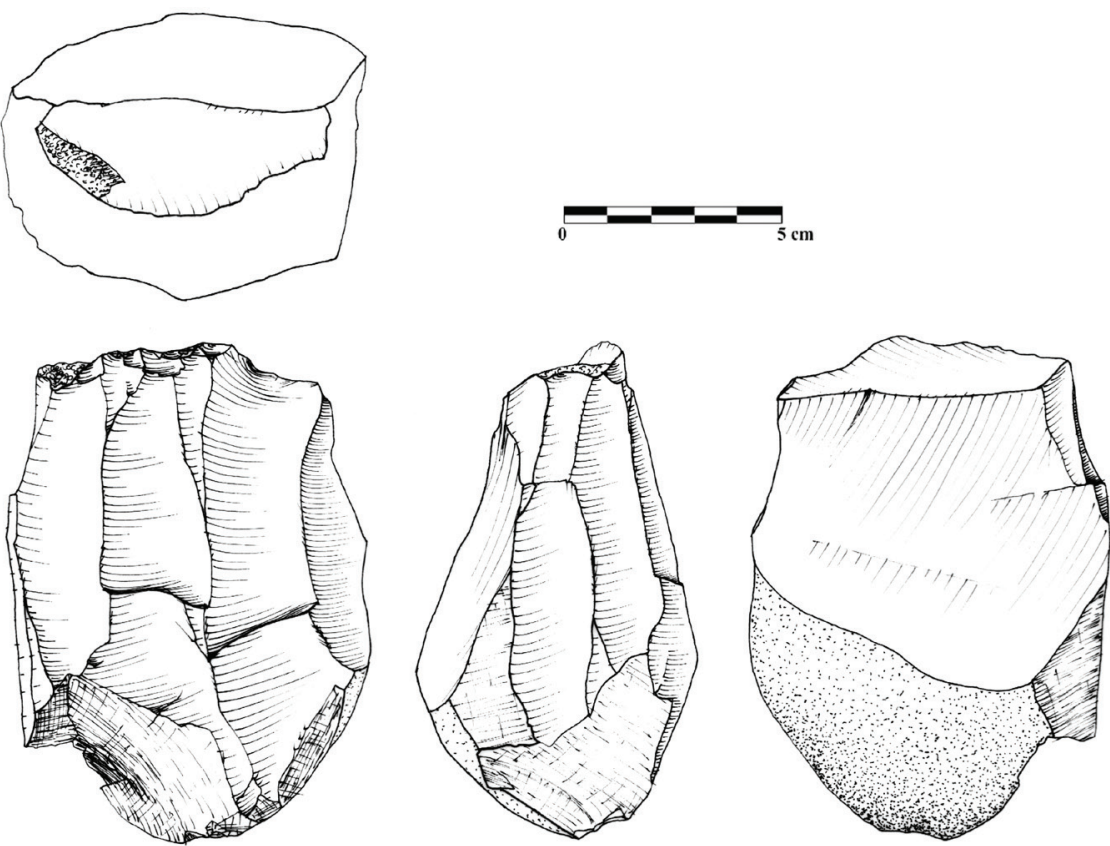

Figura 7 - ACH-LP-07. Setor 1. Núcleo laminar encontrado na superfície Fonte: Elaborada pelos autores (2016).

A esta produção laminar estão associados vários outros esquemas operatórios. Um deles visa à obtenção de grandes lascas triangulares ou quadrangulares, que são então retocadas para produzir diferentes instrumentos (Figura $8, \mathrm{n}^{\mathbf{0}} 1$ ). Nenhum núcleo encontrado no sítio corresponde à debitagem dessas lascas, mas a leitura técnica das peças atesta um alto grau de predeterminação, ou seja, de um esquema operatório específico.

A debitagem das lascas menores também ocorre. Os suportes obtidos são transformados em diferentes instrumentos. Os poucos núcleos encontrados na área de escavação reportam a produção de lascas pequenas. A debitagem é organizada em séries curtas, sem preparação prévia da superfície de debitagem, mas, após uma preparação eventual do plano de percussão (Figura $\left.8, n^{\circ} 3\right)$. Estes pequenos módulos podem ser obtidos por percussão unipolar ou, no caso de blocos de quartzo hialino, percussão bipolar sobre bigorna. Esta debitagem de quartzo é atestada por alguns núcleos e lascas, mas especialmente por numerosas estilhas (Figura $8, n^{\circ} 2$ ). As pequenas lascas resultantes da percussão bipolar ou unipolar encontradas na escavação não apresentam nenhum retoque. É provável que tenham sido usadas brutas.

O façonnage bifacial também está bem representado no nível principal do setor 1 . Pelo menos dois esquemas operatórios são atestados. Um é destacado por um fragmento apical de peça bifacial maciça, produzida por percussão interna com pedra (Figura 9, no 1). Várias lascas descobertas também se referem a este esquema de façonnage (Figura 9, no 2 a 4). Um segundo esquema visa à obtenção de peças mais leves, por percussão macia e eventualmente pressão. Uma ponta de projétil bifacial e várias lascas de façonnage se relacionam a esta produção (Figura 9, $\mathrm{n}^{\circ}$ 5). 

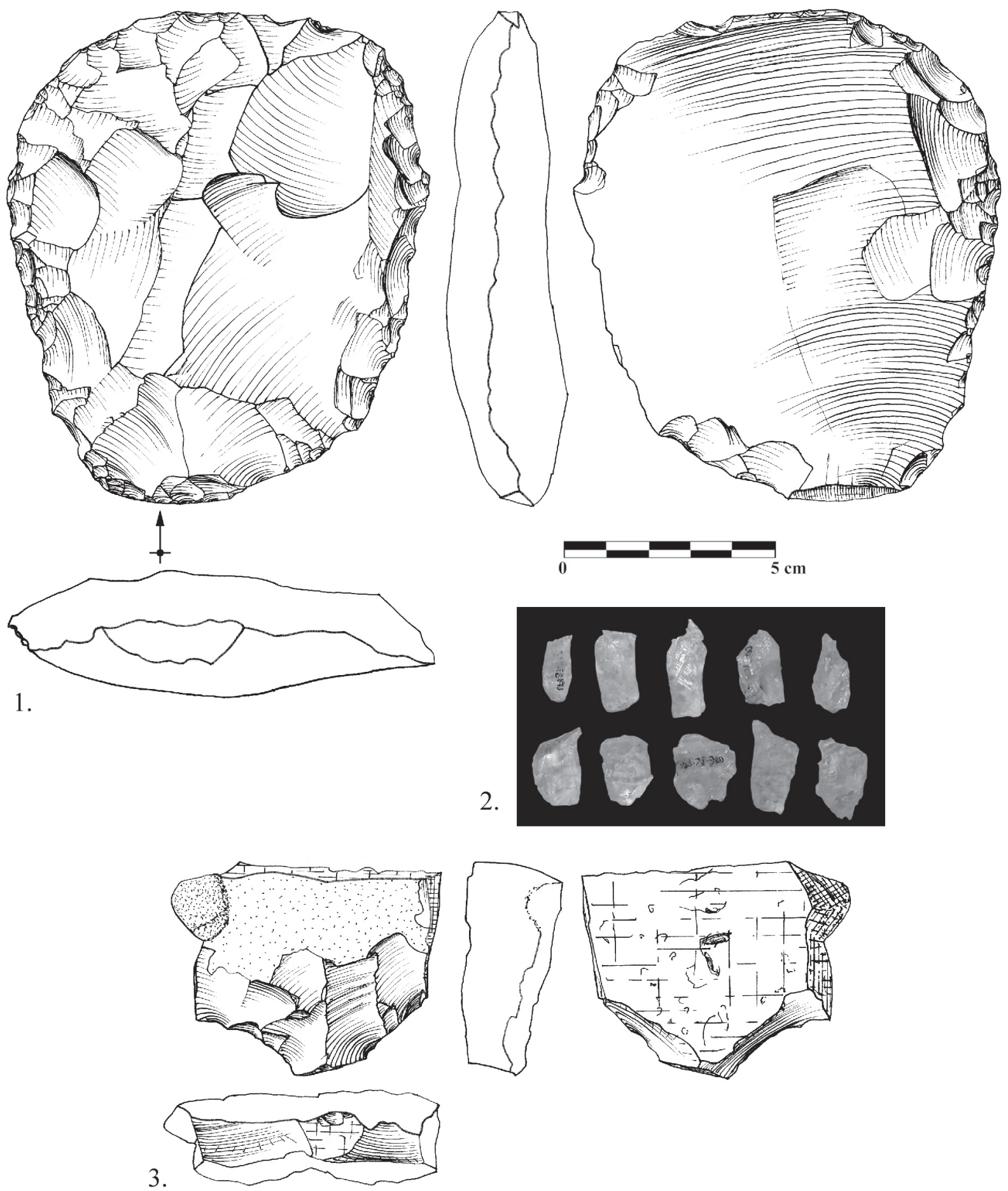

3.

Figura 8 - ACH-LP-07, Setor 1. Debitagem do conjunto arqueológico principal. 1: grande lasca quadrangular retocada, 2: estilhas de quartzo, 3: núcleo apresentando negativos da debitagem de uma curta série unidirecional de pequenas lascas

Fonte: Elaborada pelos autores (2016). 

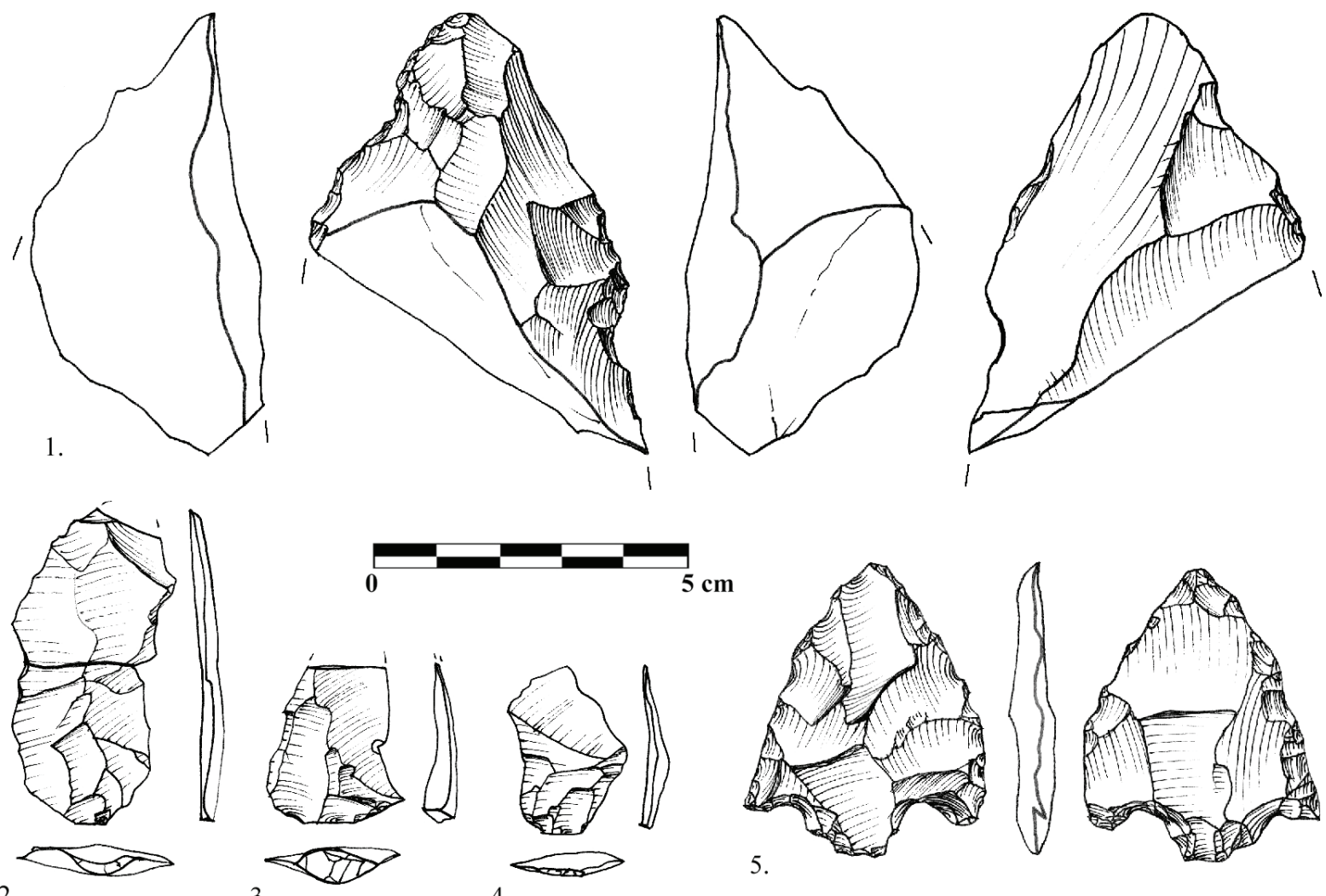

Figura 9 - ACH-LP-07, Setor 1. Produção bifacial do conjunto arqueológico principal. 1: fragmento apical de grande peça bifacial, 2 a 4: lascas de façonnage bifacial, 5: ponta de projétil bifacial Fonte: Elaborada pelos autores (2016).

\section{Vestígios arqueológicos do setor 2}

O setor 2 situa-se no topo do patamar, em um local onde aflorava na superfície a parte superior de um recipiente cerâmico de uso funerário, associado à tradição Tupiguarani. $\mathrm{O}$ mesmo foi evidenciado pelas águas de uma grande enchente ocorrida em 2014. Este setor situa-se no limite oriental do sítio preservado (Figura 2). A área de escavação é diretamente adjacente a um sedimento arenoso vermelho utilizado no aterramento realizado com a construção da barragem.

\section{Deposição funerária da unidade arqueológica Guarani}

A primeira parte da intervenção no setor 2 correspondeu à retirada do bloco contendo os vestígios do sepultamento para escavação minuciosa em laboratório. Durante essa escavação, constatamos a ausência de diferença na cor e na textura do sedimento adjacente à urna, em relação ao sedimento do resto do setor. Esse fato impossibilitou a delimitação da fossa escavada no momento do enterramento da urna.

Esse achado não é isolado. Nas pesquisas levadas a cabo por Caldarelli (2010), foram encontrados sepultamentos entre o sítio $\mathrm{ACH}$ SU3-C2 e a barranca do rio Uruguai. As datas do sítio revelaram uma idade de 540 a $490 \mathrm{BP}$ e das seis estruturas, foram escavados oito indivíduos: duas crianças, três adolescentes ou adultos e três adultos, que foram objeto de análise de Caldarelli (2010) e Müller e Souza (2011).

A estrutura funerária do setor 2 do sítio ACH-LP-07 foi retirada do contexto em bloco e escavada em laboratório (Figura 10).

Um grande vaso cerâmico (urna) foi utilizado como recipiente para acondicionar o cadáver e outro menor como tampa (Figura 11). O vaso utilizado como urna possui diâmetro de boca de $58 \mathrm{~cm}$, altura de 53 
$\mathrm{cm}$, espessura média de $10 \mathrm{~mm}$ e circunferência do ombro inferior de $192 \mathrm{~cm}$. Apresenta queima do tipo oxidada incompleta, corrugado como acabamento de superfície externo, borda extrovertida, lábio plano e arredondado, duplo ombro escalonado e formato cônico. Apresenta marcas enegrecidas e pequenos pontos de carvão incrustado na face interna, desde a base até a metade do bojo, indicando que o recipiente poderia ter sido utilizado anteriormente para cozimento, tendo sido reaproveitado como um recipiente para o sepultamento final do morto durante o ciclo funerário.
Já o vaso utilizado como tampa possui diâmetro de boca de $65 \mathrm{~cm}$, espessura média de 10 $\mathrm{mm}$ e circunferência da inflexão de $203 \mathrm{~cm}$. A altura sem a base de $26 \mathrm{~cm}$, já a altura estimada $\mathrm{em} 36 \mathrm{~cm}$. Como a base e parte do bojo não foram encontradas, provavelmente teriam sido levados pela água da enchente que expôs o conjunto. A queima é do tipo oxidada incompleta e o corrugado foi empregado como acabamento de superfície externo. A borda é direta, com inclinação de $100^{\circ} \mathrm{C}$ e apresenta formato de meia esfera. Nela, observam-se manchas escuras somente na face externa e pequenos pontos de fuligem.

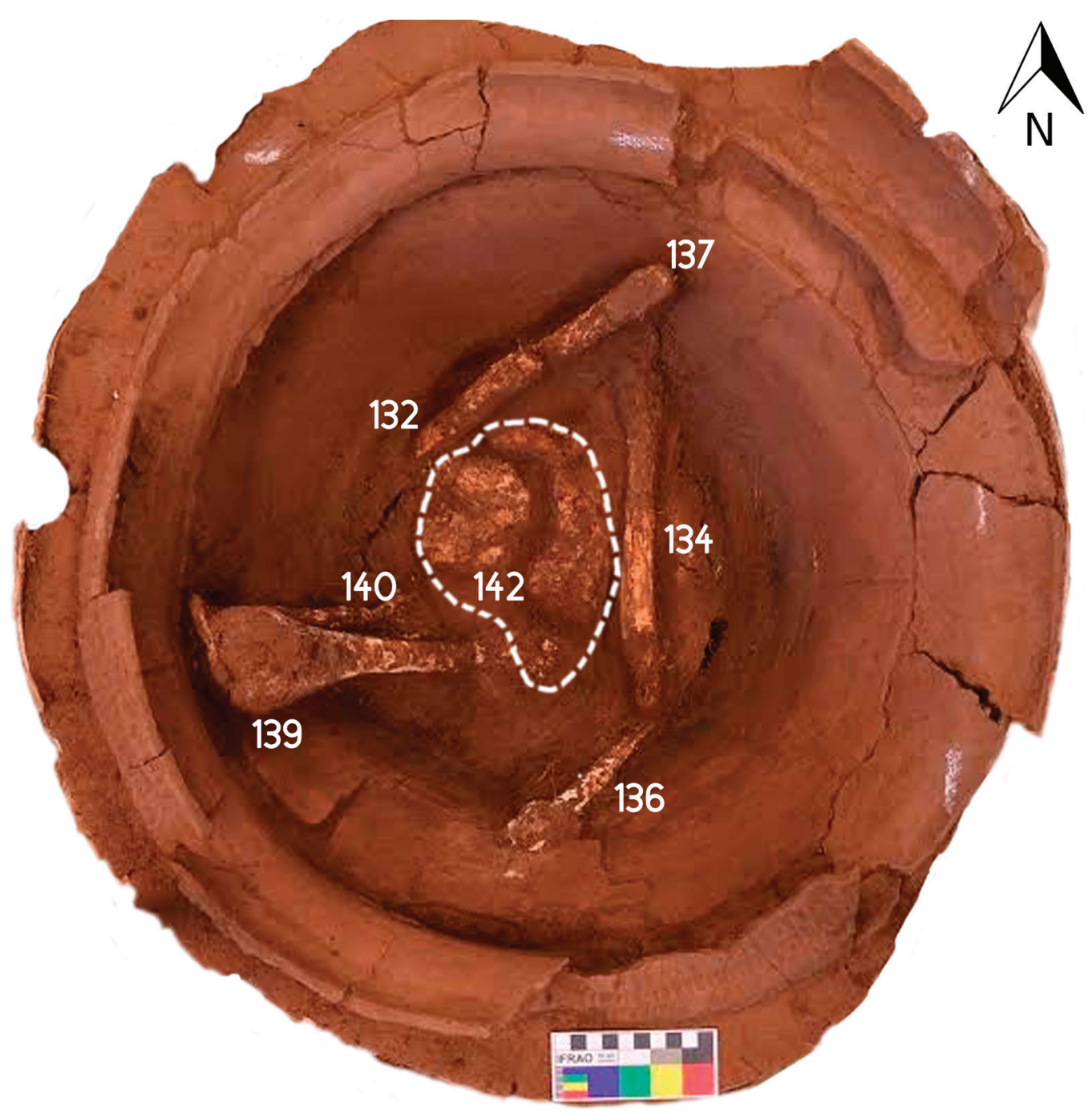

Figura 10 - ACH-LP-07, Setor 2. Deposição funerária no final da escavação em laboratório. Legenda: 139 = Fêmur esquerdo. 140 = Tíbia esquerda. 132 = Tíbia direita. $137=$ Fêmur esquerdo. $134=$ Úmero direito. $136=$ Úmero esquerdo. 142 = Bloco com o crânio e outros ossos.

Fonte: Elaborada pelos autores (2016). 

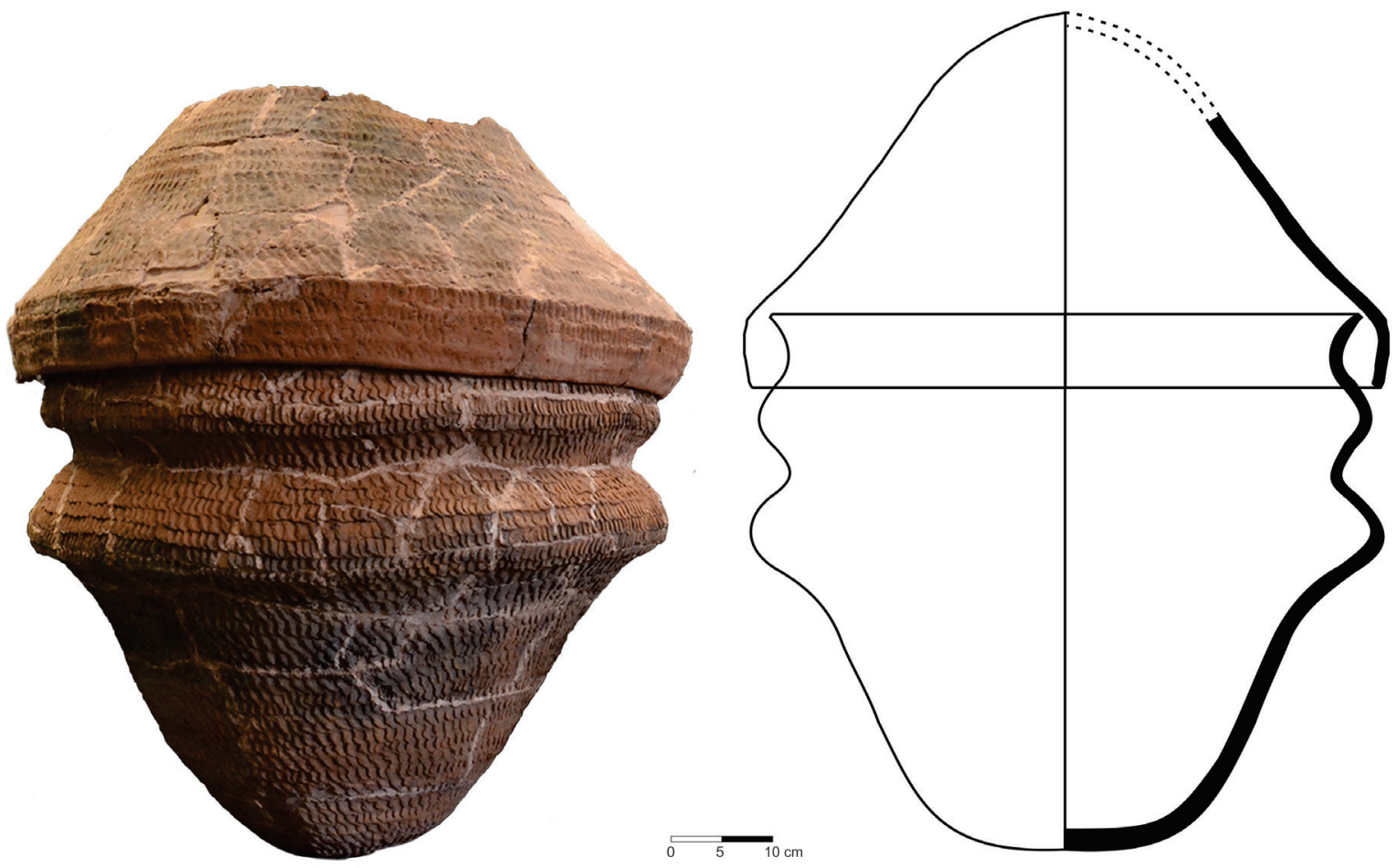

Figura 11 - ACH-LP-07, Setor 2. Vasilhames cerâmicos utilizados como urna e tampa. Fonte: Elaborada pelos autores (2016).

Ainda que a estrutura tenha sido muito modificada por diferentes processos tafonômicos, as análises preliminares permitem inferir que o sepultamento é primário, tratando-se de um indivíduo possivelmente do sexo masculino, adulto. Os ossos dos membros inferiores encontravam-se articulados e parcialmente verticalizados no interior do recipiente maior - fêmures, tíbias e fíbulas, indicando uma posição do corpo verticalizada (sentado), com membros inferiores hiperfletidos e superiores fletidos ou parcialmente fletidos. $\mathrm{O}$ crânio encontrava-se depositado sobre a região da pelve, com a porção direita voltada para baixo e mandíbula articulada. O processo de decomposição do cadáver, associado à presença de espaços vazios entre o corpo e o recipiente por um determinado período de tempo, antes do preenchimento final com sedimentos da matriz circundante, resultou em desarticulações, reacomodações e degradação dos ossos do esqueleto. A estrutura não foi ainda datada diretamente, mas pode se relacionar à idade de $395 \pm 30 \mathrm{BP}$ obtida no mesmo setor do sítio ACH-LP-07 (Tabela 4). A área onde se encontrou a deposição funerária foi utilizada por grupos da unidade arqueológica Guarani somente para sepultamento, já que no entorno não se evidenciou cerâmica, terra preta ou demais vestígios que indicariam, por exemplo, um local de moradia.

\section{Nível 1}

Ao redor da deposição funerária, a área de escavação foi ampliada, totalizando uma superfície de $12 \mathrm{~m}^{2}$. A profundidade onde a estrutura funerária foi retirada é de $70 \mathrm{~cm}$, e de $20 \mathrm{~cm}$ no resto do setor. O sedimento é argilo-arenoso de cor marromavermelhado, sem variação nos primeiros $50 \mathrm{~cm}$. Em seguida, torna-se mais claro e menos vermelho. No sedimento avermelhado, entre 15 e $20 \mathrm{~cm}$ de profundidade, foi encontrado em toda a área escavada um nível arqueológico acerâmico bastante rico composto de vestígios líticos lascados, além de blocos de basalto e de óxido de ferro sem modificação antrópica e pequenos fragmentos de carvão. Não foi identificada nenhuma estrutura.

Um total de 346 objetos líticos foram encontrados neste nível durante a campanha de 2015 (Figura 12). A matéria-prima mais comum é o arenito silicificado, seguido por calcedônia, quartzo hialino e sílex. A indústria deste nível é composta principalmente por lascas de arenito silicificado de grandes dimensões, mas pouco espessas. Os estigmas de lascamento presentes nas faces superiores atestam métodos Kombewa (debitagem da face inferior de uma lasca-núcleo), ortogonal e unidirecional. Os núcleos correspondentes a esta produção não foram 
ainda descobertos. A maioria dessas lascas não são retocadas, mas as propriedades de seus volumes, como suas bordas, são compatíveis com uma utilização sem a necessidade de retoques. Alguns instrumentos foram encontrados, incluindo denticulados. Uma única peça bifacial - maciça e façonada por percussão interna - foi encontrada neste nível até o momento (Figura $\left.12, \mathrm{n}^{\circ} 5\right)$. Assim, a indústria lítica do nível 1 do setor 2 diferencia-se nitidamente dos conjuntos técnicos definidos para o setor 1 .

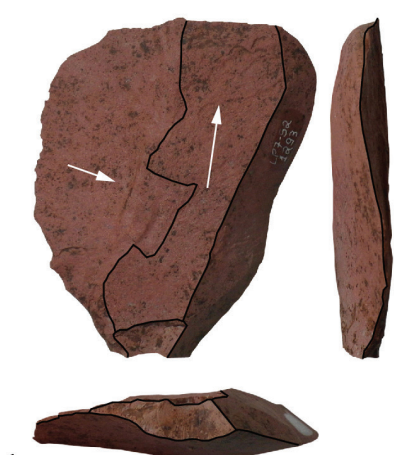

1.
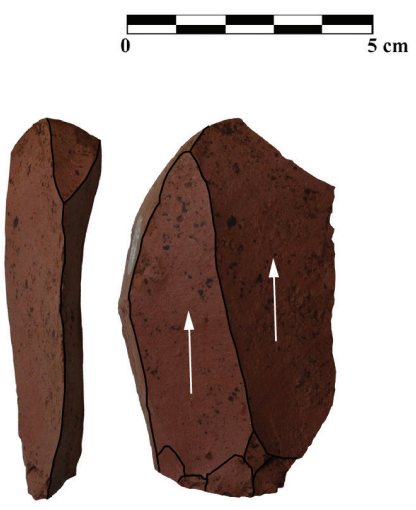

3.
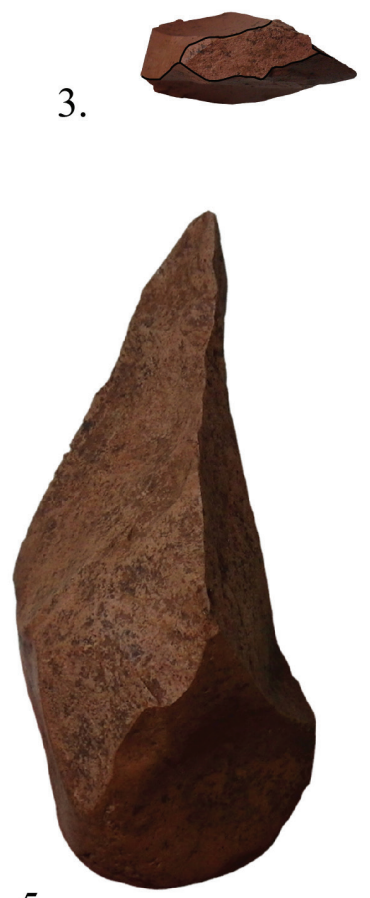

5.
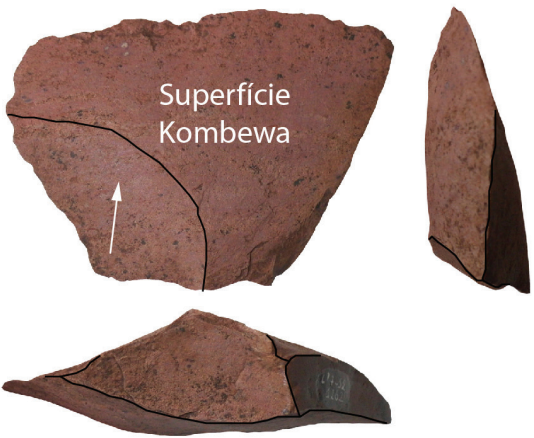

2.
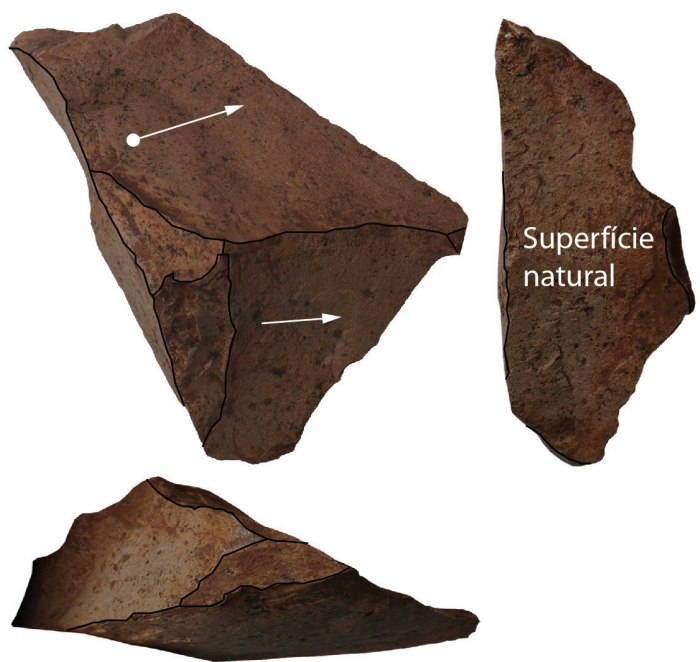

4.
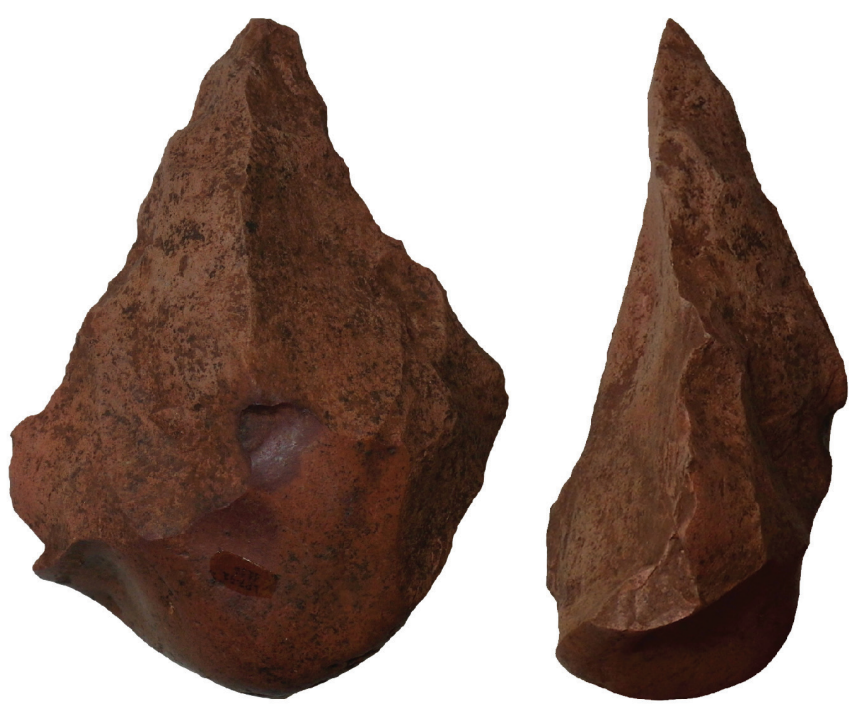

Figura 12 - ACH-LP-07, Setor 2. Artefatos líticos do nível 1, arenito silicificado Fonte: Elaborada pelos autores (2016). 


\section{Cronologia do setor 2}

As relações cronológicas no setor 2 são mais difíceis de interpretar que no setor 1. Em primeiro lugar, a relação estratigráfica entre o nível 1 e a deposição funerária não é clara. São dois conjuntos arqueológicos contemporâneos ou sucessivos? O nível 1 poderia corresponder ao solo de ocupação da população que realizou o sepultamento, mas poderia ser também mais antigo, e ter sido atravessado quando a cova onde foi depositado o recipiente funerário foi aberto. Por enquanto, vários indícios tendem a aceitar essa segunda hipótese: a ausência de cerâmica no nível 1 , o fato da indústria lítica do nível 1 não corresponder ao que se conhece geralmente das produções associadas à tradição Tupiguarani (CALDARELLI, 2010; DIAS; HOELTZ, 2010; HOELTZ; BRÜGGEMANN, 2011). Segundo Noelli (1993), a maioria dos achados não associa os sepultamentos às manchas escuras, sendo os enterramentos encontrados com maior frequência distantes das manchas de terra preta, em locais um pouco mais afastados das áreas de moradia. No caso dos sepultamentos já descritos para a área da UHE Foz do Chapecó, dado que os contextos já haviam sido destruídos pelas máquinas houve dificuldade no entendimento da localização espacial dos vestígios (CALDARELLI, 2010; MÜLLER; SOUZA, 2011).

No que diz respeito à cronologia absoluta, quatro datações por radiocarbono foram efetuadas no setor 2 (Tabela 4). No momento da escavação próximo à deposição funerária, duas manchas de cinza foram localizadas. As estruturas foram datadas com carvão proveniente de cada uma das manchas. Os resultados indicaram duas datas quase idênticas remontando ao redor da primeira metade do século XX (Tabela 4). Devido ao contexto histórico e arqueológico da região, tais datas não podem ser associadas à deposição funerária. Essas manchas e, portanto, os carvões datados devem ser oriundos das atividades relacionadas com o contexto agrícola dos habitantes da região, por exemplo, marcas de estacas de cerca queimadas.

Tabela 4 - ACH-LP-07, Setor 2. Datas radiocarbônicas por AMS (“years BP”: anos antes do presente, 1950 por convenção. "cal. years BP": anos calibrados antes do presente, 1950 por convenção. As idades foram calibradas com o programa OxCal (BRONK RAMSEY; LEE, 2013) utilizando a curva de calibração IntCal13 (REIMER et al., 2013). Os intervalos das datas calibradas são dados com 2 sigma, ou seja um nível de confiança de 95,4\%. Todas as datações foram feitas sobre carvão

\begin{tabular}{cccc}
\hline $\begin{array}{c}\text { Idade 14C } \\
\text { (years BP) }\end{array}$ & $\begin{array}{c}\text { Data calibrada }(\mathbf{2 \sigma}) \\
\text { (cal. years BP) }\end{array}$ & Num. Laboratório & Observação \\
\hline $395 \pm 40$ & {$[490 ; 320]$} & Gif13160/SacA44482 & Carvão nível 1 \\
$7.160 \pm 40$ & {$[8.010 ; 7.850]$} & Gif13161/SacA44483 & Carvão nível 1 \\
$105 \pm 30$ & {$[140 ; 15]$} & Gif13118/SacA40195 & Mancha de cinza contemporânea \\
$115 \pm 30$ & {$[140 ; 15]$} & Gif13119/SacA40196 & Mancha de cinza contemporânea \\
\hline
\end{tabular}

Fonte: Projeto Poparu (2016).

No nível 1 do setor 2, pequenos grãos de carvão foram encontrados associados aos vestígios líticos. Dois deles foram datados e os resultados foram muito diferentes: ao redor de 400 e de 7.950 cal BP (respectivamente $395 \pm 30$ e $7.160 \pm 40 \mathrm{BP}$ ). Essas duas amostras provêm da mesma profundidade e não permitem determinar de forma clara a idade desse nível 1. Contudo, estabelecendo uma conexão entre os indícios expostos acima, quanto à relação cronológica da urna e do nível 1, e o que se sabe na região quanto às datações das ocupações da tradição Tupiguarani, privilegiamos a seguinte hipótese: a data de 400 cal BP corresponde à idade da urna, com o carvão sendo intrusivo no nível 1, talvez devido a uma perturbação consecutiva à escavação da fossa para o enterramento da urna. Já a data de aproximadamente 8.000 cal BP corresponderia à idade do nível 1. Essa data do Holoceno antigo corresponde às duas datas obtidas no sítio vizinho ACH-LP-03 durante as escavações feitas pela Scientia 
Consultoria Científica (Tabela 1) (CALDARELLI, 2010). A continuação das análises, especificamente a datação de materiais orgânicos preservados dentro da urna e o prosseguimento de escavação sistemática do nível 1, permitirá confirmar ou corrigir essa hipótese.

Síntese: sequência arqueológica de ACH-LP-07

Com o conhecimento disponível no momento, a sequência arqueológica do sítio
ACH-LP-07 compõe-se, então, de quatro momentos sucessivos de ocupação anteriores aos assentamentos coloniais. O mais antigo data da transição Pleistoceno-Holoceno, outro do início do Holoceno antigo, outro possivelmente do final do Holoceno antigo e, depois de um importante hiato de ocupação, uma última ocupação do Holoceno recente (Figura 13 e Figura 14).

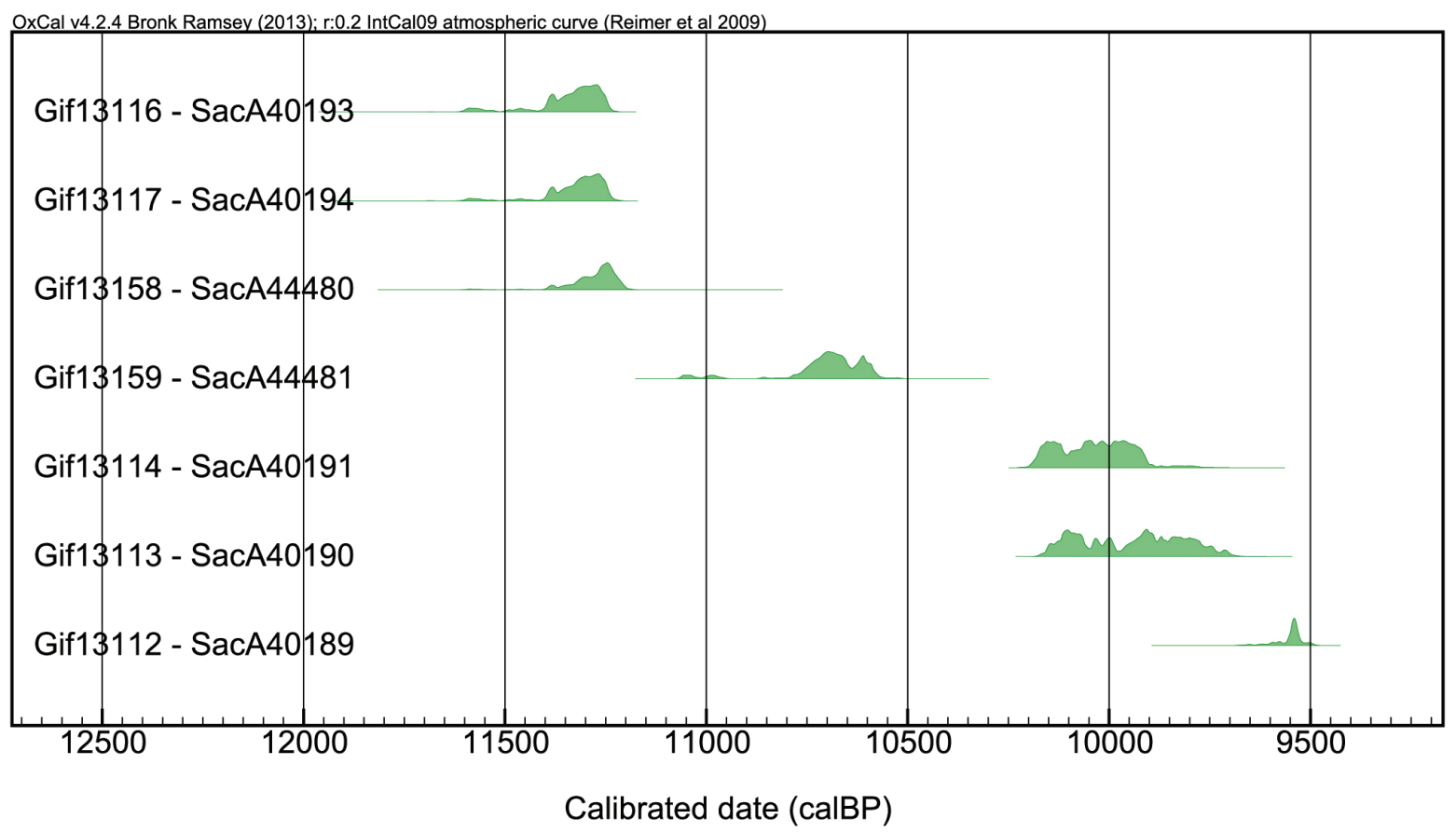

Figura 13 - ACH-LP-07, Setor 1. Distribuição cronológica das datas radiocarbônicas calibradas (a data Gif13115/ SacA40192, considerada intrusiva, não está no gráfico)

Fonte: Elaborada pelos autores (2016)

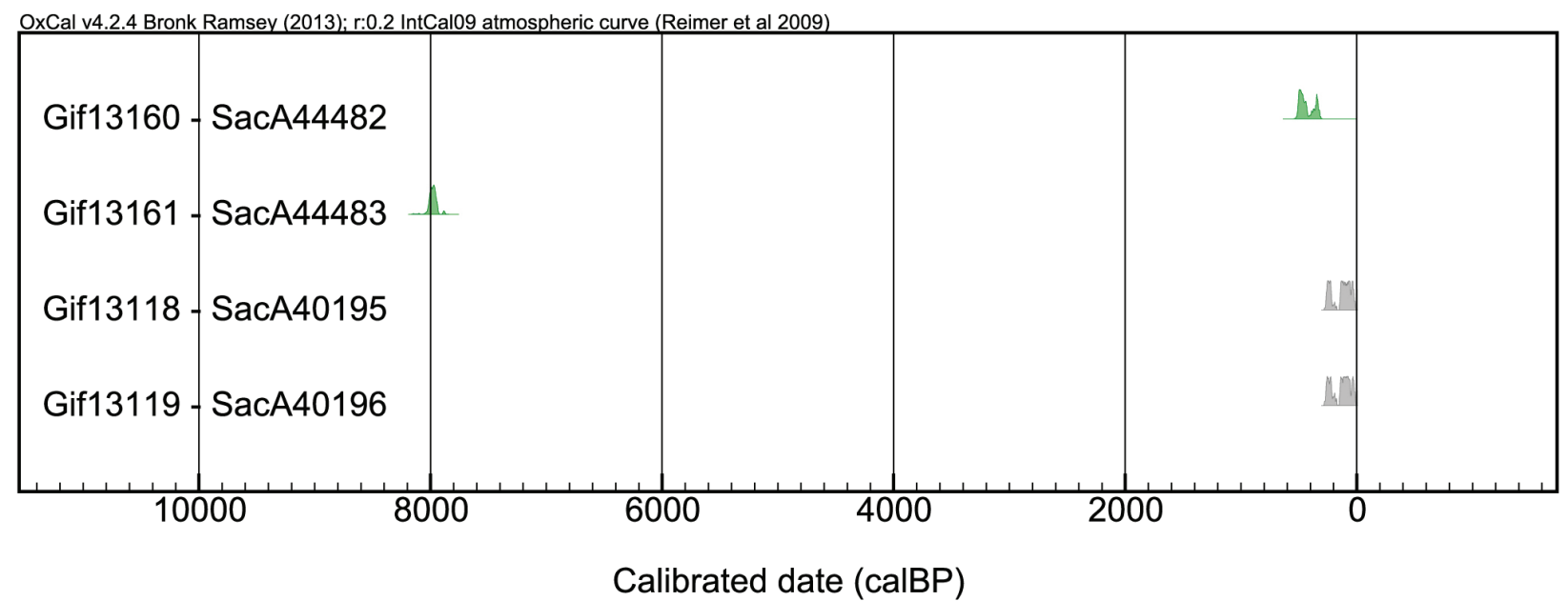

Figura 14 - ACH-LP-07, Setor 2. Distribuição cronológica das datas radiocarbônicas calibradas (as datas em cinza referem-se a áreas de combustão contemporâneas)

Fonte: Elaborada pelos autores (2016) 
O primeiro momento de ocupação de $\mathrm{ACH}$ LP-07, corresponde ao conjunto inferior do setor 1, datado entre 11.400 e 11.150 cal AP. Em razão do número reduzido de vestígios líticos nele encontrados (um instrumento sobre lasca espessa, algumas lascas e um percutor), consequência da pequena superfície escavada até agora, sua caracterização tecnológica não é ainda concludente.

O segundo conjunto é aquele para o qual temos mais dados. Consiste em vários pequenos níveis de ocupação datados entre 10.700 e 9.500 cal AP. Apresentam uma indústria lítica bastante variada, sem que seja possível até agora perceber diferenças tecnológicas entre esses níveis. Diferentes instrumentos foram obtidos por façonnage bifacial, debitagem de lascas de diferentes tamanhos por percussão unipolar ou bipolar e debitagem de lâminas. A presença de uma ponta de projétil fez associar esse conjunto à tradição Umbu.

O terceiro conjunto corresponde ao nível 1 do setor 2. Foi encontrado nele vestígios de uma produção lítica com base na debitagem bastante controlada de lascas médias relativamente pouco espessas. A data desse conjunto não está ainda estabelecida claramente, pois as duas datações nele efetuadas indicaram idades de 7.950 e $400 \mathrm{cal} \mathrm{AP}$, ou seja, antes ou depois do longo hiato sem ocupação no sítio. No entanto, definimos como hipótese mais provável a idade antiga.

O último conjunto consiste na ocupação ceramista, representada no sítio ACH-LP-07 por uma deposição funerária Guarani, cujos vestígios permitem inferir que o sepultamento é primário, possivelmente um indivíduo do sexo masculino adulto; e, embora a estrutura não tenha sido ainda datada diretamente, uma data obtida no entorno sugere que os grupos que realizaram o sepultamento o fizeram no século XVI, data muito próxima daquelas obtidas por Caldarelli (2010) para o sítio $\mathrm{ACH}-\mathrm{SU} 1$. Até o momento, não há material lítico associado a essa estrutura.

\section{A sequência do sítio ACH-LP-07 em uma perspectiva regional}

Em uma perspectiva regional, as primeiras pesquisas no sítio ACH-LP-07 contribuem de forma significativa ao conhecimento da pré-história do oeste de Santa Catarina e noroeste do Rio Grande do Sul. Juntamente com os sítios ACH-LP-01, ACH-LP-03 e ALP-AA-03, estudados no âmbito do salvamento arqueológico da área de construção da UHE Foz do Chapecó (CALDARELLI, 2010), o sítio ACH-LP-07 reforça as evidências de uma profundidade temporal importante do povoamento da região, desde o início do Holoceno. O nível inferior do setor 1 permite até mesmo posicionar as mais antigas ocupações humanas conhecidas até hoje durante a transição Pleistoceno-Holoceno, mais de 11.000 anos atrás. Com essas idades recuadas, o alto rio Uruguai se torna uma área importante para abordar e entender os processos de povoamento antigos do Sul do Brasil e da Bacia do rio da Prata.

A escavação por camadas naturais seguindo as declividades dos níveis arqueológicos e posicionando em três dimensões cada vestígio encontrado, combinada com estudos sedimentares e datações radiocarbônicas, permite uma percepção da sequência arqueológica de ACH-LP-07 com uma fineza ainda sem equivalente na região. Dessa forma, foi possível distinguir quatro momentos de ocupação: três pré-ceramistas e um ceramista. Cada momento caracteriza-se por conjuntos de objetos específicos, testemunhos de sistemas técnicos e simbólicos distintos e, portanto, de grupos humanos com culturas diferentes que se sucederam nesta área do rio Uruguai ao longo da pré-história. Dentro da variabilidade diacrônica das ocupações pré-cerâmicas de ACH-LP-07, o horizonte do Holoceno antigo, datado entre 10.500 e 9.500 anos atrás e caracterizado pela debitagem laminar, entre outras produções, é conhecido nos outros sítios desse período. Parece corresponder a uma ocupação consolidada da área por um ou vários grupos com identidade marcada localmente. Os dois outros horizontes pré-ceramistas não foram descritos até agora fora de ACH-LP-07. Pesquisas em andamento em sítios vizinhos trarão elementos de comparação para entender estes contextos em uma perspectiva regional.

A partir do exposto, constata-se que os primeiros resultados das escavações em ACHLP-07 indicam a presença de populações associadas à unidade arqueológica Guarani no final da préhistória em consonância com os dados levantados 
por Caldarelli (2010). O sítio trouxe novos elementos sobre os sepultamentos em urnas funerárias, sua escavação foi realizada com registro tridimensional em todo o processo, algo inédito para a região. Ressalta-se, por fim, que a deposição e os detalhes do método de escavação da estrutura funerária serão abordados em um artigo específico e analisados dentro de um contexto mais amplo de ocupação Guarani no alto rio Uruguai.

Agradecimentos: O projeto "Povoamentos préhistóricos do alto rio Uruguai" recebe apoio financeiro do Ministère des Affaires Etrangères et du Développement International da França. É fruto de uma parceria entre as seguintes instituições: o Centro de Memória do Oeste de Santa CatarinaUnochapecó, o Muséum National d'Histoire Naturelle de Paris e o Setor de Arqueologia da Universidade do Extremo Sul de Santa Catarina. Os coordenadores agradecem ao Instituto Goiô-En, ao Consórcio Foz do Chapecó, à Casa de Memória de São Carlos, aos professores William Zanete Bertolini e Gisele Lima da Universidade Federal da Fronteira Sul, e aos pesquisadores e estudantes que estiveram envolvidos nas atividades de campo e laboratório. Todos contribuíram de uma ou outra forma para a realização e difusão desta pesquisa.

\section{Referências}

BECKER, Í. I. B.; SCHMITZ, P. I. Uma cerâmica de tipo Eldoradense: fase Itapiranga. In: Estudos de Pré-história geral e brasileira. São Paulo: IPH/USP, 1970. p. 499-510.

BESCHOREN, M. Impressões de viagem na província do Rio Grande do Sul: Do original "Beiträge... (1875-1887) de Maximiliano Beschoren". Trad. Ernestine Marie Bergmann e Wiro Rauber. Porto Alegre: Martins Livraria, 1989.

BRONK RAMSEY, C.; LEE, S. Recent and planned developments of the program OxCal. Radiocarbon, n. 55, p. $720-730,2013$.

CALDARELLI, S. (Org.). Arqueologia preventiva na UHE Foz do Chapecó, SC/RS. Relatório Final. Florianópolis: Scientia Consultoria Científica, 2010.
; LAVINA, R. Da arqueologia acadêmica à arqueologia consultiva no oeste catarinense. In: CARBONERA, M.; SCHMITZ, P. I. (Org.). Antes do Oeste Catarinense: arqueologia dos povos indígenas. Chapecó: Editora Argos, 2011. p. 47-70.

CARBONERA, M. A tradição Tupiguarani no Alto Uruguai: estudando o Acervo Marilandi Goulart. 2008. 245 f. Dissertação (Mestrado em História) - Programa de Pós-Graduação em História, Universidade do Vale do Rio dos Sinos, São Leopoldo, 2008.

A ocupação pré-colonial do alto rio Uruguai, SC: contatos culturais na Volta do Uvá. 2014. 326 f. Tese (Doutorado em Arqueologia) Programa de Pós-Graduação em Arqueologia, Museu de Arqueologia e Etnologia da Universidade de São Paulo, São Paulo, 2014.

.; SCHMITZ, P. I. (Org.). Antes do Oeste Catarinense: arqueologia dos povos indígenas. Chapecó: Editora Argos, 2011.

.; LOPONTE, D.; SILVESTRE, R. Um contexto Itararé-Taquara no alto rio Uruguai: resultados do sítio Otto Aigner 2. Cuadernos del Instituto Nacional de Antropología y Pensamiento Latinoamericano - Series Especiales, n. 2, v. 4, p. 135-153, 2015.

COSTA, C. O. da. Indústrias líticas no Alto Uruguai: um exemplo de análise tecno-tipológica em arqueologia de salvamento. 2000. Dissertação (Mestrado em História) - Programa de PósGraduação em História, Pontifícia Universidade Católica do Rio Grande do Sul, Porto Alegre, 2000.

COSTA, S. S. da. Arqueologia no alto Uruguai: a Foz do Chapecó. 2012. 179 f. Dissertação (Mestrado em História) - Programa de Pós-Graduação em História, Universidade do Vale do Rio dos Sinos, São Leopoldo, 2012.

DE MASI, M. A. N. Relatório Projeto de Salvamento Arqueológico UHE Foz do Chapecó (Reservatório). Florianópolis, 2012. 
DE MASI, M. A. N.; ARTUSI, L. Fase Itapiranga: sítios da tradição planáltica. Pesquisas, Antropologia, São Leopoldo, n. 40, p. 99-121, 1985.

DIAS, A. S.; HOELTZ, S. E. Indústrias Líticas em Contexto: O problema Humaitá na Arqueologia Sul Brasileira. Revista de Arqueologia, São Paulo, v. 23, p. 40-67, 2010.

GOULART, M. (Coord.). Levantamento de sítios arqueológicos na Barragem de Itapiranga/SC. Florianópolis: UFSC/ELETROSUL, 1985a.

(Coord.). Usina Hidrelétrica Itapiranga: estudo de viabilidade. Culturas Indígenas do Alto Vale do Rio Uruguai. Florianópolis: UFSC/ ELETROSUL, 1985b.

(Coord.). Levantamento de sítios arqueológicos na Barragem de Itapiranga/RS. Florianópolis: UFSC/ELETROSUL, 1985c.

(Coord.). A Pré-História da Volta do

Uvá-SC/RS: Barragem Itá. Florianópolis: UFSC/ ELETROSUL, 1987a.

(Coord.). Culturas indígenas do alto vale do rio Uruguai-SC/RS: Barragem Itá. Florianópolis: UFSC/ELETROSUL, 1987b.

(Coord.). Situação atual das pesquisas arqueológicas: Barragem de Itá - SC/RS. Florianópolis: UFSC/ELETROSUL, 1988a.

(Coord.). Síntese da situação atual das pesquisas: Barragem de Itá - SC/RS. Florianópolis: UFSC/ELETROSUL, 1988 b.

HOELTZ, S. E.; BRÜGGEMANN, A. A. As indústrias líticas na área da UHE Foz do Chapecó, oeste catarinense: antiguidade, estratégia tecnológica e variabilidade. In: CARBONERA, M.; SCHMITZ, P. I. (Org.). Antes do Oeste Catarinense: arqueologia dos povos indígenas. Chapecó: Editora Argos, 2011. p. 105-136.

A. As indústrias líticas na bacia do Prata, oeste catarinense: antiguidade, estratégia tecnológica e variabilidade. FARIAS, M.;
LOURDEAU, A. (Org.). Peuplement de l'Amérique du Sud: lapport de la technologie lithique. Prigonrieux: Archéoéditions, 2014. p. 123-145.

; LOURDEAU, A.; VIANA, S. Um novo conceito de lascamento no sul do Brasil: debitagem laminar na foz do rio Chapecó (SC/RS). Revista do Museu de Arqueologia e Etnologia, v. 25, p. 3-19, 2015.

LAVINA, R. Relatório final de levantamento arqueológico do canteiro de obras da UHE Foz do Chapecó, Municípios de Águas de Chapecó/SC e Alpestre/RS. Criciúma: UNESC/IPAT, 2004.

LOPONTE, D.; CARBONERA, M.; SILVESTRE, R. Fishtail Projectile Points from South America: The Brazilian Record. Archaeological Discovery, v. 3, n. 3, p. 1-9, 2015.

LOURDEAU, A.; HOELTZ, S.; VIANA, S. A. Early Holocene blade technology in southern Brazil. Journal of Anthropological Archaeology, n. 35, p. 190-201, 2014.

\section{MUSEU DECIÊNCIAETECNOLOGIA. Salvamento}

Arqueológico em áreas do futuro reservatório da UHE Machadinho (Fase III): Relatório Técnico. Porto Alegre: PUCRS, 2001.

MÜLLER, L. M.; SOUZA, S. M. de. Enterramentos Guarani: problematização e novos achados. In: CARBONERA, M.; SCHMITZ, P. I. (Org.). Antes do Oeste Catarinense: arqueologia dos povos indígenas. Chapecó: Editora Argos, 2011. p. 167-218.

NOELLI, F. Sem Tekohá não há Tekó: em busca de um modelo etnoarqueológico da subsistência e da aldeia guarani aplicado a uma área de domínio no delta do Jacuí-RS. 1993. 488 f. Dissertação (Mestrado em História) - Programa de Pós-Graduação em História, Pontifícia Universidade Católica do Rio Grande do Sul, Porto Alegre, 1993.

OLIVEIRA, K. A cerâmica pintada da tradição Tupiguarani: estudando a coleção Itapiranga, SC. Arqueologia do Rio Grande do Sul, Brasil. Documentos, v. 11, p. 5-88, 2009. 
Um caso de "regionalismos culturais" por meio do estudo da cerâmica pintada Tupiguarani de Itapiranga (SC). In: CARBONERA, M.; SCHMITZ, P. I. (Org.). Antes do Oeste Catarinense: arqueologia dos povos indígenas. Chapecó: Editora Argos, 2011. p. 219-240.

PIAZZA, W. Notícia Arqueológica do Vale do Uruguai. Publicações avulsas do Museu Paraense Emílio Goeldi, n. 10, p. 55-70, 1969.

Dados Complementares à Arqueologia do Vale do Rio Uruguai. Publicações avulsas do Museu Paraense Emílio Goeldi, n. 15, p. 71-86, 1971.

REIMER, P. J.; BARD, E.; BAYLISS, A.; BECK, W. J.; BLACKWELL, P. G.; BRONK RAMSEY, C.; BUCK, C. E.; HAI, C.; EDWARDS, R. L.; FRIEDRICH, M.; GROOTES, P. M.; GUILDERSON, T. P.; HAFLIDASON, H.; HAJDAS, I.; HATTÉ, C.; HEATON, T. J.; HOFFMAN, D. L.; HOGG, A. G.; HUGHEN, K. A.; KAISER, K. F.; KROMER, B.; MANNING, S. W.; NIU, M.; REIMER, R. W.; RICHARDS, D. A.; SCOTT, E. M.; SOUTHON, J. R.; STAFF, R. A.; TURNEY, C. S. M.; VAN DER PFLICHT, J. IntCal13 and Marine13 radiocarbon age calibration curves 0-50,000 years cal BP. Radiocarbon, n. 55, p. 1869-1887, 2013.

ROHR, J. A. Pesquisas arqueológicas em Santa Catarina, os sítios arqueológicos do município de
Itapiranga. Pesquisas, Antropologia, Porto Alegre, n. 15, p. 21-60, 1966.

Achados arqueológicos em Itapiranga. Pesquisas, Antropologia, São Leopoldo, n. 18, p. 49-65, 1968.

A pesquisa arqueológica no Estado de Santa Catarina. Dédalo, São Paulo, n. 17/18, p. 49-65, 1973.

Sítios arqueológicos de Santa Catarina. Anais do Museu de Antropologia da UFSC, Florianópolis, v. 16, n. 17, p. 77-168, 1984.

SCHMITZ, P. I. Um paradeiro Guarani no Alto Uruguai. Pesquisas, Antropologia, Porto Alegre, n. 1, p. 122-142, 1957.

Trabalho de Salvamento Arqueológico nos locais das Represas do Alto Uruguai, RS/SC. In: CENTRAIS ELÉTRICAS DO SUL DO BRASIL S/A. ELETROSUL. Bacia Hidrográfica do Rio Uruguai: Estudo de Inventário Hidroenergético. Apêndice IV e V. Florianópolis: Eletrosul, 1978. p. 93-97.

SILVA, O. P.; MONTICELLI, G.; DOMIKS, J. Levantamento do Patrimônio Histórico, Cultural e Arqueológico na Área Diretamente Afetada pela Usina Hidrelétrica Foz do Chapecó. Relatório de Atividades. Itaconsult Consultoria e Projetos em Arqueologia Ltda., Florianópolis, 1998. 